\title{
Popular, religious and social movements: Recent research approaches and qualitative interpretations of a complex of historical problems
}

\section{By Vagn Wåhlin}

The popular movements were a major factor in the efficient Danish path to modernisation 1800-1970. In a positive interaction of a number of factors from 1840 - a liberal market economy, a rather non-corrupt public sector of the state and local governments, general education of children and the expansion of democracy - the popular movements together with their associations and institutions organised the social and mental potential of Denmark's civil society.

The loss of Norway in 1814 and later in 1864 of the most affluent regions of the realm, the duchies of Slesvig and Holsten, could easily have caused a total breakdown of the Danish state and society. ${ }^{1}$ A short period of mental shock occurred, but the remaining Danish realm, inwardly strengthening its potential, found a way to overcome the deep-rooted conflicts between the urban-industrial and agricultural modes of production and their respective mentalities. So a triangle of state, market and civil society was, on the one hand, in constant inner conflict materially and mentally for a long time and yet, on the other hand, resolved this conflict, not by an open conflict of winner and loser, but by a balance of power and by co-operation to the mutual benefit of the whole of society. In mutual and mediating co-existence with the state and the market it has been especially in the civil sector, but also in economics, politics and mental-cultural matters that the popular movements have exercised and still exercise their deep influence on Danish society and on what is really Danish in the 'land of associations', where N. F. S. Grundtvig was the right man, at the right time, at the right place with the right programme.

The intention of this article is not to give a brief definition of the popular movements in a lexical sense in order to indicate their nature as social phenomena. ${ }^{2}$ Instead, I would prefer to demarcate and, in particular, to consider systematically the problem area both thematically and in its historical context. In addition, in presenting some research in the field of popular movements, I would like to propose a new interpretation as well as to outline some interdisciplinary ways of approach. In support of the discussion I have produced a more detailed diagram of all the main groupings of popular movements (a few pages ahead) and, as well, I have shown the dynamic and procedural models for parts of the movements in Figure I, II and III.

It is to be regretted that, due to the numerous details, I have been obliged to pass over parts of the stricter Christian theological and ecclesiastical differences and dimensions of some of the movements. 
As regards the most significant recent debate on N. F. S. Grundtvig $^{3}$ and on the meaning of the Grundtvigian inheritance today after Postmodernism, I refer the reader to Kim Arne Pedersen's outstanding summary of the topic in his article entitled 'Grundtvig på anklageboenken' ('Grundtvig in the dock') in Grundtvig-Studier 2002, 184-251. The popular movements and their network of organisations gave both a space and a voice to the basic aspirations arising from $\mathrm{N}$. F. S. Grundtvig's thoughts and activities, which in the $19^{\text {th }}$ and $20^{\text {th }}$ centuries changed Danish society in so many ways. The history of Grundtvig's impact on society cannot be understood and described without a thorough and comprehensive study of the popular movements, even if the social effect and significance of these movements consisted of more elements than those inherited direct from Grundtvig himself.

A short outline of the Danish way to modernity during the Period of Absolutism (1660-1849) ${ }^{4}$ is needed to clarify certain major traits in the Danish social and cultural development. This will make possible a better understanding of the societal role played by both the strong influence of the popular movements as well as N. F. S. Grundtvig's contribution in this field by being the right man, at the right time, at the right place, with the right programme and finally a better understanding of the deep impact of the interaction of those two factors with the rest of society.

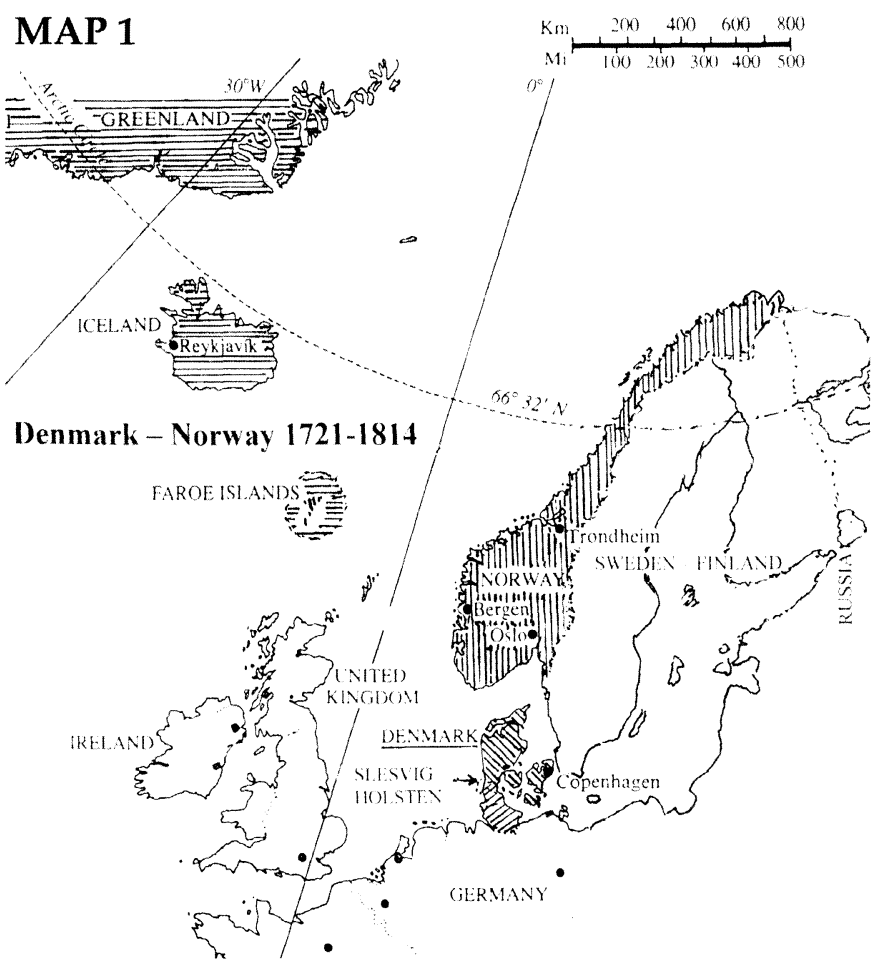


MAP 1: The kingdoms of Norway and Denmark ("the twin realms") with dependencies in the North Atlantic were united by a royal inheritance in 1380. For more than 300 years, up to 1660 , Denmark-Norway was involved in a constant double confrontation over the dominance in Scandinavia, on the one hand by the kingdom of Sweden-Finland and on the other by the dukes of Holsten and Slesvig, each with his own allies. Sweden finally gained the upper hand and nearly annihilated Denmark in 1660. The "twin realms" were only saved by the major European powers, which would not accept Sweden's domination of the trade in the Baltic and its becoming too powerful in the region. After a civil war, the former mediæval Catholic Church in Denmark was reformed in 1536 into a strong and centralised, Lutheran State Church for everyone, which after the year 2000 still counts more than 80 per cent of the population in its 2,000 parishes as the "people's church" (Folkekirken). In the long peace between 1721 and 1801 both the centralised political power of the Period of Absolutism (1660-1849) and Denmark's economy (trade, agriculture, fish and timber) flourished in Denmark-Norway. That made possible a dual inner transformation of Enlightenment and Modernisation in many areas including the rule-of-law, impartial justice (1790s), general education for girls as well as boys (1814), a fair and efficient administration, protection of woodlands (1805), a public local poor relief system (1802), fire insurance systems and especially general agricultural reforms (1788) - the latter mostly to the benefit of the social middle layer of the peasant farmers.

Denmark's involvement on the French side in the Napoleonic Wars (1807-14) became a national catastrophe: Norway was lost to Sweden and the peaceful settlements over Slesvig-Holsten of former years were threatened. Nationalism as legitimisation of political power arose throughout Europe as a consequence of the Napoleonic Wars. The German-speaking duchy of Holsten and the Germanophile upper classes of Slesvig soon constituted an explosive internal problem for the remaining unified state of Denmark and the duchies of Slesvig, Holsten and Lauenburg (the latter gained in 1814). No one could know for certain whether or not the peace settlements of 1814-15 would stand; the German public under the guidance of the leading North-German power of Prussia from 1840 was constantly interfering in the troubled DanishGerman national conflicts in the unified Danish state. The internal national problems of the Danish state system were followed by a bloody civil war and by the two Danish-German wars of 1848-50 and 1864, ending in the loss of the duchies to Prussia (see comments to map 2.). Yet the Danes and their king in the midst of a civil war could agree on a new democratic Constitution of 1849 , which with later implementations is still in function in 2006. But just as the Constitution meant much for democracy and citizen involvement in public affairs on the national level, so the introduction of strong and broadly elected municipal and county boards between 1837 and 1841 meant equally much for civil involvement on the local level. The third great factor on Denmark's path to modernity was the impact of the popular movements on all levels of society, as well as their organisations and more permanent institutions, which is the theme of this article.

From a middle-size European state up to 1814, Denmark had to accept from the $19^{\text {th }}$ century the role of a small state with little possibility of manoeuvring on its own in international politics. On the other hand, precisely this factor gave national energy and time to proceed on the path to modernity 
with great success internally and the rise of an economically sound and democratic welfare society in the $20^{\text {th }}$ century. For all its deficiencies Denmark generally does well when compared to most other modern societies and has come near to Grundtvig's ideal of 1820 as a society: "where few have too much and fewer too little".

It is amazing that one single person, Grundtvig, through more than a hundred years has been and still is so dominant, both in Denmark and in a number of places abroad, for an understanding of very specific Danish concepts, which are nowadays widespread in Denmark. Amongst such concepts are:

- 'åndelig' i.e. spiritual in the broad sense as opposed to material

- 'det danske' that which is typically Danish

- 'folk' the people or nation

- 'folkelighed' ${ }^{5}$ the quality that typically sums up the Danish nation as a political entity and its people, in this sense of 'Danishness' and folkelige bevagelser, popular movements.

These and many more words and concepts are all inventions of Grundtvig, but are now part of the ordinary Danish vocabulary and in daily use also by non-Grundtvigians i.e. those who do not embrace his philosophy. The dominance of Grundtvig's personality can be seen, not only in many of his concepts that have spread beyond the Danish borders, but also in the fact that the Centre for Danish Studies at the University of Lund, Sweden, established in 2001, held a panScandinavian conference on this phenomenon in 2002. The proceedings of this conference are now (2003) available under the title of Grundtvig - nyckeln till det danska? (Grundtvig - A key to what is essentially Danish? $)^{6}$. The editors have with justification placed on the dust-cover the rhetorical question 'nämn den svensk som skapar sådan debatt 130 år efter sin död' ('name the Swede who is creating such debate 130 years after his death').

The central issue in the Danish ${ }^{7}$ and Swedish contributions to the book is partly to throw light on aspects of the history of Grundtvig's spiritual influence, which has helped create the Danish identity and partly - but unfortunately expressed less explicitly - on how the history of Grundtvig's impact has been expressed purely concretely in social terms through the heirs to the older popular movements e.g. in the life of the national Danish Church of today as 'Epoch' or 'Era' (Tidehverv) $^{8}$ and in politics as the nationalist and populist Danish People's Party (Dansk Folkeparti). ${ }^{9}$ The authors of the book do not have much sympathy for these newer movements and their leaders, and they regard the assertion by Tidehverv and Dansk Folkeparti that they also have inherited the legacy and thoughts from Grundtvig within the life of the Danish people more as an act of violence rather 
than an act of devotion. They seem unaware that Grundtvig saw things from a very different angle.

Although the editors of the book are aware of the influence of the context of Grundtvig's texts, the essential paradox here is that these expert observers avoided the obvious fact that Grundtvig's words and opinions were not merely spread by themselves. They were printed over a hundred years ago and they played an important role in influencing and changing Danish society and mentality. "How?" one might ask. As I see it, every message of Grundtvig should of course be read, re-interpreted, spread and accepted afresh as being relevant to each generation and to each new social grouping. Otherwise, there is no history of their impact, but only the eternal silence of the past. That is to say, someone has to do something in order to spread the message, or else it is not heard, and someone has to do something to receive it, or otherwise it will not gain any wider significance - except within a very little group of 'bookworms' and 'ink-pots', if I may now describe it in Grundtvigian terms. And this someone who is committed and this something which activates society are both just the organised religious, cultural, social and political stirrings amongst the common people. From this impact there has arisen the life of the movements and their associations, clubs and more enduring institutions, such as meeting houses, private 'free schools', ${ }^{10}$ newspapers, occupational organisations etc., which when gathered together constitute the popular movements.

\section{FIGURE: POPULAR AND SOCIAL MOVEMENTS IN DENMARK}

On the following page there is a survey in diagrammatic form of the most important types of popular movements. Each sub-group in the diagram contains in itself often hundreds, indeed thousands, of voluntary nongovernment associations, clubs and institutions. In about 1914 there were in all of Denmark a total of 1,253 Christian-religious local Inner Mission groups,${ }^{11}$ whose estimated membership of 250,000-400,000 met in a little over 800 mission houses, while at the same time the dairymen in the agricultural sector delivered milk to 1,400 co-operative dairies - or nearly one in every parish of Denmark ${ }^{12}$ In 2003 there were about 11,000 independent clubs, gathered under only one of the two large athletic and sport umbrella organisations, the Danish Athletic Association (Dansk Idrcets Forbund). ${ }^{13}$

Denmark was and has continued to be a 'land of associations', with an immensely large number of voluntary organisations, covering practically all areas of social life. These organisations, catering for individuals and groups on one social level and functioning collectively on another, have often arisen in most cases from or have connection with the popular movements as the practical social tools for their ideologies. Seen from the social perspective, they involve systems of clubs, organisations and institutions for the higher, middle and lower classes, men and women, young and old - even the immigrants of the last 30 years with their network of clubs, Islamic private schools etc. have appropriated part of Denmark, 'land of associations' for 
themselves. $^{14}$

The time-line below the figure gives approximately the year that the movement, club or institution became viable.

The agrarian/urban divide in each part of the diagram has its point of origin in two empirical facts that the social conditions between about 1800 and 1960 have varied greatly between the country and city and that the capital city of Copenhagen from 1800 has been so independent and strong, comprising in the year 1900 about a quarter of the total population, so that it totally dominated the urban sector as the central city.

On the other hand, the people in the agricultural sector - especially the lower middle-class peasant-farmers - were able to create their own systems in deliberate opposition to the capital, Copenhagen:

- culturally, e.g. the folk high schools, ${ }^{15}$ independent private schools and meeting houses etc.,

- economically, e.g. co-operative dairies, co-op saving banks, co-op slaughter houses etc., ${ }^{16}$

- politically, the farmers' Left Party, (Venstre, 1870), newspapers, ${ }^{17}$ etc.,

- religiously, the Inner Mission and the Grundtvigian movements and organisations and in

- youth work, e.g. youth clubs with a Grundtvigian/liberal orientation and the Inner Mission's YMCA and $\mathrm{YWCA}^{18}$ - even if physical culture in the form of athletics, sports and gymnastics and the YMCA and YWCA (in Danish KFUM and KFUK) and like organisations had penetrated far and wide throughout both the country and city.

After 1920, the clear agrarian/urban distinction slowly became less significant because of the growth of both provincial and railway-towns and migration from the country to the city, even if about half of the population at that time still lived in the country or in very small rural townships. The agrarian/urban divide could still be seen in the movements and in club-life right up to $1960 / 70$, i.e. until the time when the successful welfare state and the agrarian and industrial society were superseded by both post-industrial training and the information society and by individualistic and egocentric post-modernism. This new society is characterised by its current radically changed forms of life, its diluted class structures, its changed family patterns with 90 per cent of Danish women out in the labour market and the children taken care of in such institutions as kindergartens, schools and youth centres and only 3-5 per cent of the population employed in agriculture.

The area of validity of the diagram is from 1800 to $1960 / 70$, but I have nevertheless indicated two important instances concerning the most recent period of history 1970-2006. The first point is that the older network of associations and clubs and the system of institutions has often been able to adapt to changes within new areas of activity and thus they are still in existence or have been revitalised (e.g. many club houses and meeting houses). The second point is that new, single-focus movements with looser structures and horizons, shorter than those of the old popular movements, have captured society as new social movements, often with meaningful penetration, and thus articulated the wishes of very many people committed to the specific goal of the movement. 


\section{POPULAR, RELIGIOUS AND SOCIAL MOVEMENTS IN DENMARK 1800 - 1960/70}

LIBERAL/ NATIONAL PATRIARCHAL CONSERVATINES SCOUTS COMMUNITY SINGLECASES
DEMOCRATIC
SINGING

clubs lib./democr.t. labour-movem. party

periodicals newsp.tassoc. readingroom/co-op. newsp. technical society

$\begin{array}{ll} & \text { Vietnam-anti-war } \\ \text { evening } & \text { resistance mov. anti-atom mov.t }\end{array}$

TEMPERENCE Jodge/temp. association

temperance fades

CHRISTIAN

Dan. Bibel. Soc.t.

WOMENSLIB. Dan. Wom. Society

$\begin{array}{ll}\text { Copenhagen } & \text { YWCA } \\ \text { Home Mission(IM) } & \text { FDF YMCA } \\ \text { Internt. peace mov.t } & \text { One World } \\ \text { Radicale Left party } & \\ \text { + small holders } & \\ \text { Politiken ((Rad.L.newsp) } & \end{array}$

Venstre Party, nat. org. 1929

LABOUR MOVEMENT

Social Dem. Party

Dan. Soc. Dem.Youth

nationl trade un.s

co-operatives beer $/$ bread $/ \mathrm{milk} /$ coal/groser

newsp/evening school labour high schools still alive, some plac.s thriving redstockings closed 1995

pro-Euro Union

\author{
PHYSICAL CULTLRE \\ riffe associations \\ local gymnastics $\&$ athletics compete \\ ball-games regional competition \\ sports ansd games widespread \\ national unions of clubs
}

\section{Labour mowement now often fossiliced,}

institutions closed

Liberal P. but now not farmers $P$. SF, VS Enhl.

Youth not in trade un.s syndicates

most out of business often closed

since 1950 sports etc

(are the most

( numerous of all po-

(pular movements. -

(membership 8-10

times more than the polit. parties)

\section{URBAN WORLD above the line} the urban-agrarian division line AGRARIAN WORLD beneath the line became less significant

AGRARIAN MOVEMENTS at the religious-ideological level

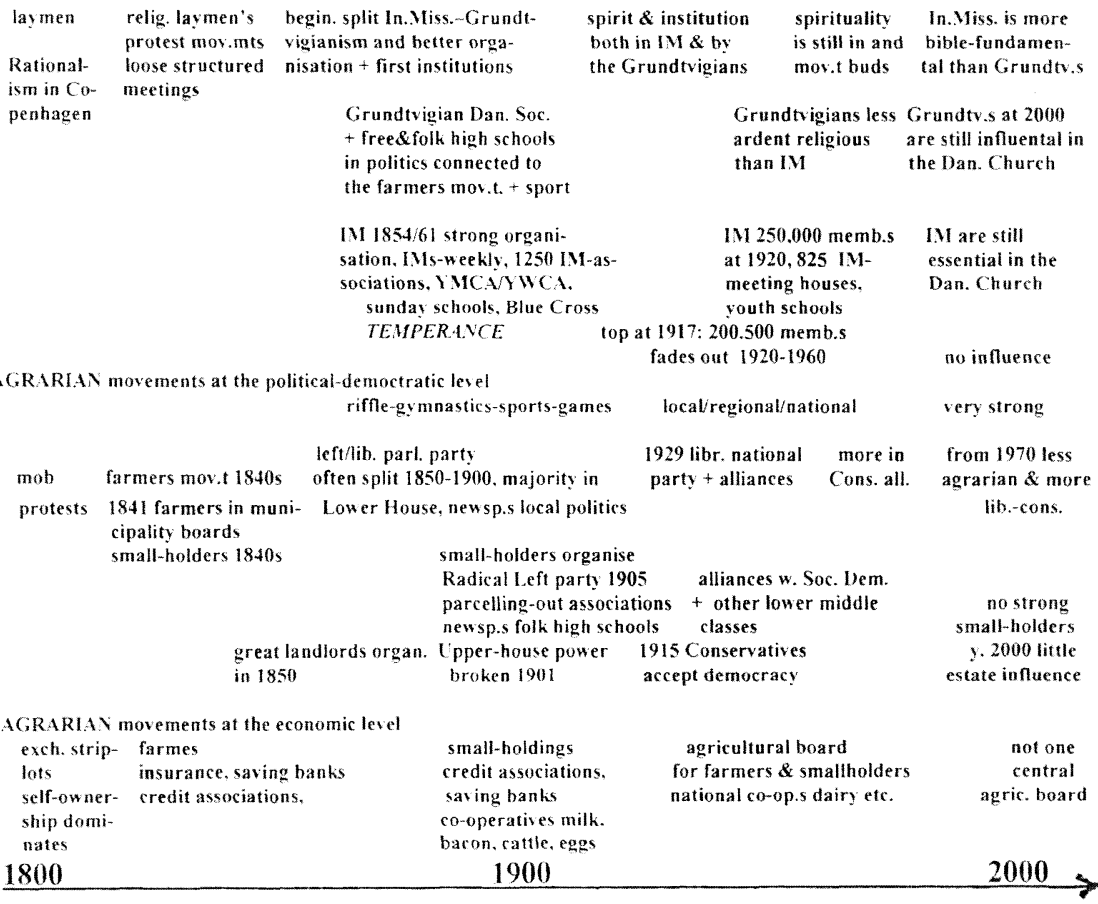


The political constitution underlying the Period of Absolutism ${ }^{19}$ was the constitutional Royal Law (Kongeloven) of 1665 and the general Danish Law (Danske Lov or DL) of 1683, which operated together as the legal framework in everyday life for the Danish population as the parallel Norwegian Law (1687) did for the Norwegians. From then on, it was expressly forbidden for the population to assemble publicly in any organised manner, unless such gatherings or meetings were directly permitted or occurred incidentally according to ancient custom, such as a Mayday celebration or a wedding party, or were even directly prescribed, such as a congregation in a church, a soldier in the army or individuals participating in a craft guild or a regular village meeting.

The central issue was that all members of society - except the king himself - were themselves subject to the principle of pyramidical control and supervision, where those above in the system were responsible all the time for those below them i.e. the officer for his soldiers, the ship's captain for his sailors, the master for his journeymen, the householder for his household and his farmhands - as it was prescribed in DL, Book VI, chapter 20, paragraph 2:

Concerning the Professors (who should) have diligent Supervision with the Exercises of the studying Youth and hold them to the Fear of God, Obedience towards their Superiors, Modesty, Proper Behaviour, Peaceableness and Sobriety and let no Indecency, which is committed by them, go Unpunished. [The capitalisation of the original $17^{\text {th }}$ century text is followed, V.W.]

Common opinions and behaviour could also be created in another way, e.g. through printed material and posters. Therefore, there was also a strict general censorship of all printed material until the 1770s and in the rest of the Period of Absolutism, even if it were less severe before 1849. It was the state that upheld censorship of newspapers and periodicals, which comprised printed matter less than 50 pages. Grundtvig himself was put under strict censureship between 1826 and 1837 by a court decision. It was even worse if anyone sought to create public feeling against particular people or civil servants, about which DL, VI, chapter 21 stipulated:

If anyone is shown to have written or posted a bill, Defamation or Lampoons on honourable People, and his Name has not been made public, then he should lose his Honour, and go in Irons for the rest of his Life on the Island Holmen [the strictest state prison] or another Place: if it is (committed) against the Public Authorities, (let him) lose his Neck. ${ }^{20}$

That is how it was - "Off with his head!" - if one seriously breached 
the strict system of responsibility and obedience. Free and open criticism, as well as just mere meetings of the common people, were not allowed.

In the same restrictive spirit the Conventicle Decree (Konventikelplakaten) $^{21}$ was promulgated in 1741 against a series of religious meetings of lay-persons (konventer) of a pietistic type, ${ }^{22}$ which were just beginning to appear at that very time. Apart from family devotions, the parson or his deputy was thenceforth authorised to permit and, if necessary, to be present at devotional meetings of any type. The above-mentioned regulation of 1741 was often used against devotional meetings at the beginning of the $1800 \mathrm{~s}$, but in actual fact it ceased to be of effect by about 1840 .

\section{Legalised and tolerated public expressions of opinions and discontent}

Any organised behaviour of the king's subjects, not directly permitted, was thus in principle controlled or directly forbidden during the Period of Absolutism. So how could a public protest against unfair treatment and devastating social conditions be expressed or ever reach the ears of the rulers before discontent broke out in open rebellion? Several forms of legal contacts were in use during the time of absolute rule, the more significant being:

- The petition

- Constructive criticism through recognised societies

- Public arenas for general expressions not directly allowed, but tolerated as

- Clubs and private associations for closed circles after 1780, and student associations after 1820 etc.,

- And last but not the least debating articles in periodicals and newspapers in a rising number after 1771

- all were parts of an expanding public opinion between 1780 and 1848 .

The Petition (Suppliken) was either a petition written directly to the absolute ruler or a request for personal appearance before him to present orally a written petition or complaint. It was a frequently used means, partly amongst the subjects face to face with the king and partly for him to read and hear himself what was going on among the population and how the administration was functioning. Such written petitions are preserved in thousands in the state archives, but they have not been properly used in research. Yet in individual cases it was indicated that the petitions actually functioned as a pressure valve for popular discontent and this fact confirms the good reputation that royal power held amongst the populace. 
Constructive criticism was also an important factor for expressing public matters, which need to be corrected. From the middle of the 1700 s several societies were established by royal decree or with the king's permission, such as the Royal Danish Agricultural Society (Det Kongelige Danske Landhusholdningsselskab, 1769 onwards), ${ }^{23}$ having the right to publish periodicals etc. Behind closed doors matters of the society could be discussed reasonably freely, even with criticism of important social questions, as long as the tendency of the criticism was not directly pointed at the king. Indeed, after 1750 those in power and the government were during the Period of Enlightenment really interested in constructive criticism and well-grounded proposals for improvements, expressed in a suitably urbane form from an increasing part of the public.

Public expressions, such as clapping, cheering and catcalls during dramatic productions, such as those at the influential Royal Theatre in Copenhagen (Det Kongelige Teater, 1770 onwards), could function as an expression of public opinion during the latter Period of Absolutism, just as books published in a proper academic form often became the subject of an early public debate, both in writing in reviews and orally at club meetings. General meetings of legally sanctioned organisations, such as the Copenhagen Fire Assurance Society (Hovedstadens Brandkasse) $)^{24}$ were used to influence public opinion on social conditions. Likewise, conversations of law-abiding citizens in respectable coffee houses performed a similar function in the late 1700 s and early 1800 s.

The clubs also played an important role in the development of freedom of expression. It was first with the growth of the middle-class clubs in Copenhagen from the 1770s that a genuine modern forum for discussion was established on English and Dutch models and then spread from the capital to the larger provincial towns. If we take into consideration the number of citizens involved and the degree of affluence which was to be found amongst Copenhagen's some 60,000 inhabitants at that time, no more than scarcely 5,000 men could have had the time and the wherewithal to participate in the new clubs and associations and be counted as regular readers of the rising number of periodicals and newspapers. By other means we can estimate that between 1,000 and 2,000 males were actually active in club life - seen in relationship to the 5,000 potential members. There is no question that there was a high percentage of participants. From the nature of Absolutism it is clear that the government wished to have both formal and informal control and inside knowledge of this new public forum. Information on the forums was gained amongst other means by spies, of whom a contemporary says '... when eavesdroppers and toadies partly tell tales on what could have been said in such places ... ${ }^{, 25}$ for this reason the clubs had to shut their doors against non-members. This 
public control was ensured when club life was controlled by a decree of $1780 .{ }^{26}$ Consequently, all clubs and societies had to report to the police, hand over a copy of their laws and indicate particularly who were on each executive committee and who stood at the head as chairman. By this means the leaders could be made responsible for everything undesirable that could happen. Thus there was no prohibition, but rather control, and again the pyramidical system of responsibility was maintained.

The political organising of students and later of the Liberals became a significant factor. In 1820 university students made use of the already mentioned model for clubs for the founding of the Student Union in Copenhagen, declaring their intention to create primarily a scientific and aesthetic forum for debate. The authorities clearly saw through the political aims which lay behind the request to create an academic and political public space, but the state nevertheless allowed the setting up of the Student Union from the point of view that it would be easier to use spies to keep an eye on what went on rather than to forbid it. On the other hand, in 1831 the left-wing radical artillery captain, A. F. Tscherning (1795-1874), sought permission to set up a discussion club, the 'Twenty-eighth of May Society', which on the surface looked equally respectable. However, permission was refused because of the political element in the planned club. Instead, Tscherning and his circle arranged public banquets with speeches and singing, which the authorities permitted. These well-attended events continued for some years. In a similar way, around 1840 enthusiasts for the pan-Scandinavian cause were denied permission to form clubs but, when they had removed the most politically controversial members from their committee, they were permitted to organise under a different name as Det Skandinaviske Selskab (The Scandinavian Society) in $1843 .^{27}$

Meetings of the Estates became an issue after the July Revolution in France in 1830, spreading to most European countries so that the new middle-classes received some form of elected political representative bodies. ${ }^{28}$ The Danish government was pressured into introducing meetings of a new form for the Estates from 1834, with the first meetings taking place in 1835 and 1836. In both the clubs and the organisations and also in the newspapers in Copenhagen the elections to the representative estates led to increased political activity. The resultant 'insolence in writing' so irritated King Frederik VI that he was considering a tightening of the censorship laws. This aroused the anger of the moderate, liberal burghers of Copenhagen and the provincial cities, and within a short time they had established in 1835 the country's first mass-organisation, The Society for the Correct Use of the Freedom of the Press (Selskabet til Trykkefrihedens rette Brug) with 5,000 members. From this time on that society, being ack- 
nowledged by all sides, functioned as a buffer between the government, the more rabid journalists and those with liberalistic tendencies.

The anger of the lower class was also a significant issue at the time and in the public understanding of the necessity of an acceptance of channels for expression of public distress. By means of The Society for the Correct Use of the Freedom of the Press and like associations the educated citizenry could find a balance between Absolutism and a publicly expressed desire for freedom. But deeper in the sea of society, amongst the economically pressed petits bourgeois and the proletarian, unemployed hand-workers, anger and a deep social dissatisfaction was raging. This dissatisfaction was expressed again and again from the 1830 s at night with placards posted on the city's walls - which the police next morning just as diligently tore down again, hiding them in the Police Archives, such as the following:

Your Majesty, if you want to avoid the Frustration and Anger of the People, then Provide Work for the People and the Revival of the Food Trade, (...) before it is too late! Know, Your Majesty, that You are for the People! And not the People for You;

or concerning other class tensions against the young academics:

[write nevertheless about] the infamous and Vulgar Behaviour, which the Danish Students have shown in a Neighbouring Kingdom of [Sweden (...) they get drunk in gin shops and chase lecherously after petticoats and] come home to their Lodgings at Night-time as well as in the Day-time, full of liquor, smash everything to pieces, make a Mess of everything and cheat their Landlords of the Rent. All this is the pure Truth and no Lying. And these People want to rule the Country and the Kingdom. ${ }^{29}$

Urban middle-class movements were very influential in shaping a general public debate and preparing the Danish society for democracy. These movements included the young liberal academics, who spoke so warmly in the 1830s and 1840s about 'the people' (folket) and 'freedom'. It was of course scarcely the writers of these placards and other tens of thousands in the lower level of society that the academics were thinking of, but rather themselves.

The central issue is that decades earlier, when religious meetings in the countryside were spreading, the Copenhagen middle-class and the lower middle-class and many young academics became involved. They were now well acquainted both with forms of printing and with the modes of operating an ideological and political public and of organising an effective break-through. The immediate reason for the coming of the Danish Constitution and democracy in 1849 had its origin in the wars of 1848-50, but a more fundamental cause was to be found in two main circumstances: firstly in the provisional alliance 
between a politicised class of peasant-farmers and the liberal movement called 'The Society of the Friends of the Farmers' (Bondevennernes Selskab) of 1846, secondly in the fact that the liberal citizenry in Copenhagen was ready to rock Absolutism and to take over power but could only do so in an urban-agrarian class alliance of the middle layers of society, cf. note 17.

From state patriotism to national movements - German and Danish in rising opposition

Absolutism in Denmark was not in principle 'national' in the modern sense of the word; loyalty from the officials and the people was connected directly to the king - as the king's most loyal subjects - and not to an impersonal state. These loyal subjects often included competent foreigners, who did not have roots in or loyalty to be bonded to any conglomerate state's national or social grouping within the population. The Citizenship Law of 1776 formed a transition from royalty to a patriotic patriarchalism, in which loyalty to the state was seen to be a desirable addition so that the government officials were born in and felt themselves to be a part of the king's realm. But since the mother tongues of the officials and the citizens were in practice German, Danish, Norwegian, Icelandic, Low German, Frisian or English (e.g. in the West Indies and India), in this connection it was less important which language one actually spoke. The official languages for the administration were Danish and German.

Beginning in Holsten in the first decades of the 1800s and soon spreading to the upper-class and urban citizens, there developed against the background of the Napoleonic Wars a consciousness and an assertion of a Germanism and a German cultural and historical precedence in the duchies. These tendencies were fostered by the requirement by the central government in the early years of the $19^{\text {th }}$ century that Danish in the duchies should enjoy the same status as German, e.g. with the promulgation of all laws and ordinances in Slesvig in both Danish and German, where they formerly had been published just in German, and similarly for the Danish-speaking population of North Slesvig. 


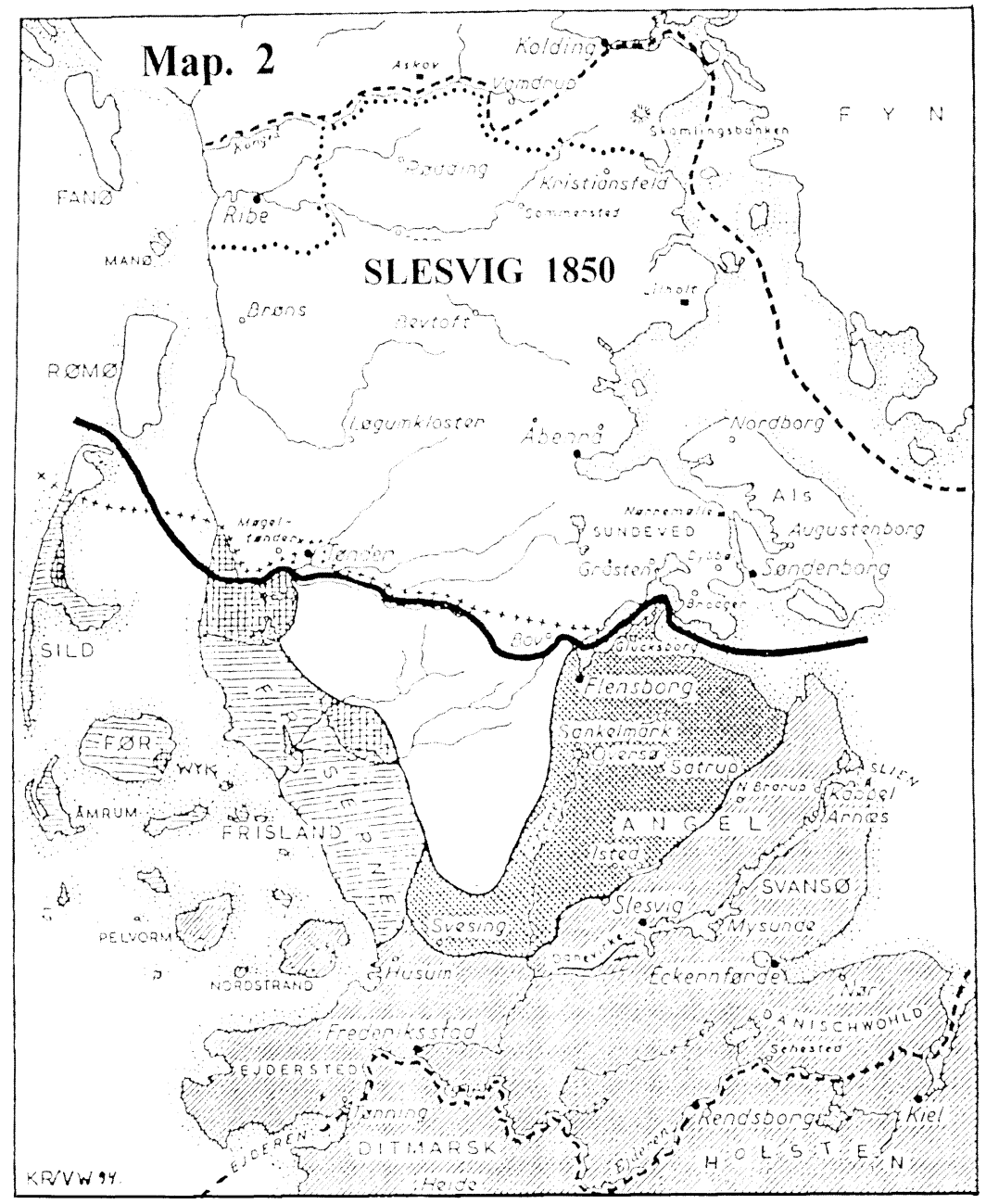

State border today as in 1920

I=-m- Slesvig border to DKdIlusten 1864

$\bullet \bullet \bullet$ State border 1864-1920

+++ South line for Danish language in school and church

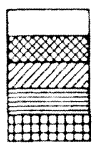

Danish language

mixed Danish/German

lowgerman

Frisian

mixed Danish/Frisian

Languages in Slesvig: Since the Viking-and the Middle-Ages the Frisians along the West Coast and the Low-German speaking Saxons and other Vorth-(ierman peoples from Holsten - and especially the nobility - have advanced North into the old Danish landscape Slesvig. By intermarriages between the I Holstenian and Slesvigian nobility and by migration of German crattsmen and merehants into the Slesvigian towns the situation before 1850 looked like demonstrated by Map. 2. When a linguistic national conflict between Danish and (ierman arose from 1840 it became an explosive situation that was first solved as fair as possible in 1920 with a referendum. 
The landed aristocracy of Holsten had for a long time had its own representative body, die Ritterschaft (the Estate of Chivalry) for its interests, which were connected, even if hesitatingly, to the growing nationalist German middle-class currents, which were to be found in, amongst other places, the University of Holsten in Kiel. The contempt of the Holstenian landed aristocracy for the liberal tendencies of the urban middle-class were, however, slowly overcome by their common economic and social interests with the larger landowners in Slesvig. The local ducal line in Slesvig (descendants of the Danish royal family) of the Augustenborgers was frustrated because of their lack of real power. When they soon legitimised the German and later the Slesvig-Holsten national causes, then a marriage of convenience was arranged between the aristocratic landowners and the German nationalistic-liberal middle-class. That coalition won broad public support in Germany from the 1830s and created the background for a pan-German cultural and political alliance against Denmark's centurylong political domination in the Twin Realms.

The occasion of the combined national German manifestations and the following civil wars from 1848 to 1850 were political expressions of Danish nationalism in the meeting of Slesvig's estates in the 1840s and other places, but the causes lay much deeper: firstly in Denmark's vulnerability as a little state after the loss of Norway in 1814; and secondly in the European nationalistic movements, to which, amongst other things, Prussia with its aspirations of pan-Germanic rule had harnessed the chariot of its aggressive foreign policies around 1840; and finally in the Danish Liberals' double recognition of their own weakness against King Christian VIII's intelligent utilisation of the deep-rooted absolutism and of the popular strength and efficient appeal in a nationalistic Danish programme. Consequently, they changed almost over night in 1842 from the Liberals to the National Liberals, Denmark's first political party. Through the strong Danish national feeling they had finally gained a cause with a popular appeal that could be used in their political struggle and striving for power. But even with this cause on their banner, the urban Liberals could not get the better of royal Absolutism, except in an alliance with the new middle middle-class in the country and the peasant-farmers of the agrarian sector. Such a coalition was finally successful for a number of the National-Liberals in 1846 with the formation of the Society of Friends of the Farmers (Bondevennernes Selskab) that soon numbered far more than 5,000 members, mostly peasant-farmers. This society dominated the elections outside Copenhagen to the Estates and the Parliament in the late 1840 s and the early 1850 s, especially on Zealand and the larger islands, cf. note 17. 
Popular meetings of a nationalistic and patriotic type began in the 1840s with Steen Steensen Blicher's Himmelbjerg festivals in the lake highlands in the middle of Jutland ${ }^{30}$ which soon attracted an audience of thousands. At the Skamlingsbanke meetings from 1843 - attended in 1844 by 12,000 participants - the more modern nationalistic Danish line and along with it the anti-Slesvig-Holsten line were drawn more sharply by such things as having Grundtvig as the main speaker in cooperation with well-known National-Liberals and some respected Slesvigian farmer leaders. ${ }^{31}$ The national Danish success was strengthened by the lack of success of the contemporary pro-German Slesvig-Holstenian meeting near the North-East Slesvigian town of Åbenrå. These mass-meetings were the very first political meetings of that kind permitted by the authorities - earlier public manifestations of the masses had been wanted and planned by the authorities as expressions of loyalty to the royal family or to the nation at royal weddings or declarations of peace or as the millennial celebration of the introduction of Christianity in 1826 etc.

The prevailing line and feeling of patriotic loyalty to the state in the leading circles from the 1770s on - supported by the old fashioned allegiance to the king by and of the farming population - was supplemented from the first years of the 1800s in the culture of the refined circles with National Romanticism. That form of Romanticism was a part of a general European influence, but now with a conscious Danish inclination along with a middle-class idyllic symbolism and a self-contented sense of Danish cosiness. The people in oral tradition and folk-costumes, in history and landscape, on ordinary days and on festivals were discovered or invented by painters and composers, by poets and ethnographers etc., but were up to this day given life and form to a particular degree by N. F. S. Grundtvig. In prose and song, in politics and polemics, in speech and in writing Grundtvig, more successfully and with deeper impact than any of his contemporaries, was able through the years to unite Christian and national, historical and cultural, scenic and linguistic resources and expressions into a many-facetted sense of that remarkable and still today collective concept, the Danish people, as among other foreigners the SwissAustralian Hans Kuhn has pin-pointed in Defining a Nation in Song. Danish patriotic songs in songbooks of the period 1832-1870 (1990).

Neither the terms Danish nor people could be or can be defined logically or rationally. For this reason many of today's academics and researchers remove the phenomenon by calmly proclaiming its logical and social non-existence. Along with Benedict Andersson's Imagined Communities (London, 1983) they relegate it to a merely imaginary or 
purely fictitious sphere. On the contrary to 'imaginary' I would like, in agreement with historical facts from the past and the present, to assert without hesitation that words have the potential to kill and 'dreams' are realised as people's collective social actions that create social and national realities - which we today consider to be regression, stagnation or progress - as e.g. the terms Danish and popular. New generations will dream new dreams in new communities, in which the dreams become words and 'the words create what they signify' ${ }^{32}$ - as the tree is known by its fruit.

In the Danish category of the four estates, these groups up to the late Period of Absolutism were officially defined as the king's loyal subjects and not as Danes, Norwegians or Germans. Despite roots back to the Middle Ages and understood in contrast to that which was especially Swedish, German, French or Latin, the people first arose as something other than the population. 'Danish' in a modern understanding, beginning in the late 1700 s and spreading out to many in the $1800 \mathrm{~s}$, became the predominant mental current in the 1900s. I am quite in agreement with this understanding of B. Anderson and other theorists. But this agreement does not at all mean, as proposed by Post-Modernist philosophers, that 'Danishness' (danskhed) and the people (folk) - which is the Danish national feeling, - are or should be a stage of the past, seen from the perspective of the history of mentality or consciousness as a sort of petty and ridiculous collective puberty infatuation. $^{33}$

As far as I can see, in the light of (a) the new millennium's external nationally and nationalistically manifested reality from the Balkans to Russia etc. and (b) the internal Danish scepticism in the broad strata of the population towards the European Union and globalisation, the 'Danishness' and the people first die away when or if these indefinite mental and social realities concerning people and nationality are no longer chosen and defended, and re-appropriated and renewed by and for the people, individually and in common. As Grundtvig has also so often defined, ${ }^{34}$ the national - as opposed to one-eyed nationalism was and is an identity-creating way of seeing, understanding and expressing the ego and the society as well as the world in relation to religion or art or membership of class or sex groupings as a framework for interpretation. If we look at the large number of today's ethnic and political conflicts, there is not much evidence that indicates that the national and popular aspects are phenomena of the past in the course of history. In this sense, the national resource is a progressive daily personal referendum on membership of society on the individual level as well as on the collective level with quite serious consequences for the individual and for society in the world of action and of reality. Conversely, it is obvious that many - perhaps the majority - of today's Danish élite, who are internationally oriented, multilingual, norm- 
setting and open to cultural change and who are to be found amongst today's politicians, leaders of organisations, business people and academics might see the national aspect of the mentality as an obstacle to progress. In this instance it is the people and 'Danishness', which are a hindrance in relationship to their understanding of the world around them and as a straight-jacket for the development of their possibilities. Thus this élitist attitude is in line with the way the international capitalists perceived the industrial workers' self-defence of their class in the trade unions 100 years ago or the nobility perceived the peasants' narrow local horizon 300 years ago or the churchmen in the Middle Ages perceived the shallow cultural background of the unlettered classes from the point of view of the ecclesiastical community and its Latin mentality. In modern times - as in olden days - it is the people without money, without higher education, without knowledge of foreign languages and today without aptitude for IT, who will pay the bill for globalisation. The resultant burdens of class struggle are levelled today in the third millennium at the lowest stratum of the population by the élite of the society - even if with a more human face than the rather undisguised and often quite brutal acts of oppression of earlier times. ${ }^{35}$

The national aspect in the understanding cited above i.e. the people and Danish identity became throughout the 1800 s a link in the selfperception and history of the whole of Denmark and of its people, like a keynote which also penetrated many of the other movements with one or another objective and which in these years set something social into motion. The leader of the Christian Inner Mission, Vilhelm Beck, ${ }^{36}$ maintained thus for many years the precedence of 'faith in salvation', as the one requisite, which over politics and of the day and of the country was able and necessary to bind people together in one large Christian community, but already before the late 1890s Beck publicly acknowledged his 'Danishness'. J. Skjoldborg's songs for the hundred of thousands of small-holders and cottagers from the beginning of the 1900s do not have the national state, the flag or the common history of Denmark as symbols which convey nationality and create identity. ${ }^{37}$ But, instead, he stressed hard work in the Danish landscape, the changeable weather and the dream of a modest piece of Danish earth - and not of a farm in America - as the symbols conveying nationality. Socialism as an ideology was international, but the Danish workers' movement and its Social Democratic leaders were both national and communal about the time of the First World War and were able to have been brought together with such a slogan as the following words of Oscar Hansen's very popular song of 1934, still in use: 
Place for all of them,

Place for all who want

Denmark for the 'people'.

Here there is no talk of 'the Slave Army of Hunger' nor of 'the Age of the Workers' as in earlier labour songs but of the time of the people, not of revolution, but of co-operation of all inhabitants who want the common good in a Denmark for the people - where workers and farmers, office-workers and intellectuals, men and women are pulling together on the same end of the rope, where the people and the land are one. Those with cool brains will here remember that the song was written in the middle of the world crisis and just after the great Kanslergade Compromise of $1933,{ }^{39}$ where the farmers of the LiberalLeft Party, the small-holders of the Radical Left Party and the workers from the Social Democratic Party entered what was until then the biggest national agreement, a compromise on the regulation of agriculture and social reform. This agreement was and still is seen by many observers as the founding of the modern welfare state and the greatest victory for co-operative democracy, but it was seen especially by the Marxists as the final class treason. ${ }^{40}$

We can well pass over how the relationship between the native soil and local and regional patriotism can be seen in the light of the national dimension and of the experience of the average person. Such issues as regionalism in Slesvig appear so embedded in the national aspect of the fight for North Slesvig that the strength of Slesvigianism has been overlooked up to $1970 .^{41}$ In the same way the flourishing of an active and organised interest of more than 200,000 people in local history and culture since 1970 is strong evidence that geographical dimensions other than Denmark as a whole are at stake in the formation of identity.

\section{Non-Class based movements - the women and the temperance}

The urban bourgeois and the middle middle-class farmers of the $19^{\text {th }}$ century, the labour and the small-holder organisations of the $20^{\text {th }}$ century, all with their ideological (religious) and practical associations and organisations, were in general class-based social phenomena, while sport and athletics in general were cross-class movements so that even a single local club, especially in its earlier years, could be somewhat class-restricted. Social class and especially education played also a part in the spreading and membership of the women's and temperance movements, yet class was and is not a key prerequisite in the life and work of those two movements. 
principles in its policy and practice. The former agrarian village traditions of cottage industries and the accompanying overconsumption of alcohol became impracticable as the $19^{\text {th }}$ century progressed. Moreover, they became outdated with the spread of a more rational work ethic, modern and dangerous machinery, general enlightenment and education and a public understanding of the grave social consequences of the misuse of alcohol. Upon joining a Temperance Society, the prospective member took a public pledge to uphold the principle of temperance and promised to abstain from all forms of alcoholic beverages. In principle, the pledge was for life and could be taken by men and by women, young and old. In wellorganised subsidiary institutions, often based on a co-operative model, the Temperance Societies soon covered all aspects of life from the cradle to the grave.

Discipline was maintained mostly by the application of psychological pressure and fear of being expelled from the local association, which could have severe mental consequences, especially for the many lonely young people who had migrated to the industries in the towns and cities. On the other hand, a young worker involved in the temperance movement could easily be excluded from the company of his work-mates, where the consumption of alcohol was high, traditional element of everyday life. There was no strict borderline between the two major systems of organised temperance, but the majority of the more petit-bourgeois Temperance Orders were predominant in the cities and the more democratic Temperance Associations were predominant in the countryside and the smaller new towns, which had often developed on railway junctions.

In Sweden the temperance movement had good and close relations, on the one hand with the labour movement and on the other to the different Christian currents and Free Churches. However, the situation was the opposite in Denmark, where the labour movement saw temperance as a splitting of the essential sense of solidarity needed in all aspects of life amongst the working class and the various workingclass institutions. Indeed, only a few examples are known in Denmark of an individual's rise to influence through dual membership of labour and temperance.

Both the Grundtvigians and supporters of the Inner Mission saw the wine in the Sacrament of Holy Communion as having been instituted by Christ himself and as being an indicator of the fact that the use of alcohol in itself could not be contrary to religion - it was the human weakness in the misuse of alcohol that was the problem. Even when, after Vilhelm Beck's death in 1901, the Inner Mission took over the Blue Cross, the Danish branch of an international temperance organisation, thus giving the leader of the Inner Mission a dual directorship in practice, there were in general no co-ordinated 
temperance activities in or between the two strong movements inside the State Church. Hence, in practice, the advocates of temperance were fishing in the same ideological waters as the Christians and as competitors they often regarded each other with suspicion. But the temperance movement gained great support on both the individual and the organisational level from socially active women, as in many other Western countries. Women supporters of temperance also found broad support from the liberal-minded middle classes before 1900, because the backbone of society, the family, was seen to be strengthened in this way. In addition, working-class women found a ready-made forum for social expression and an initiative in the temperance movement, and they were often trained for later social engagement through this involvement.

As with other popular movements and organisations, it is difficult to give more definite statistics of membership of the different branches of the temperance movement, but a valid guess is 250,000 - or some 10 per cent of the population - at the peak of the movement's popularity at the time of the First World War. The great temperance goal of total prohibition by law was never attained in Denmark as it was in America, yet a few municipalities became "dry" some 70 years ago by local option referendums, but never to the same extent as in Sweden. In 1917 the government doubled the consumer price of alcohol overnight for various reasons and the intake per capita fell dramatically over many years. So did the membership of the temperance societies, and today they number only a few thousand, a mere shadow of their former strength - ironically enough, at a time when the alcohol consumption per capita is higher than ever before and alcoholism once again is a serious social problem. It is difficult to measure in exact terms or statistics the influence the temperance movement exercised on society on Denmark, but in any case it contributed much to the diminishing of some of the severe problems on the path to modernity both in the agrarian and the urban sectors of Danish society. ${ }^{42}$

The women's movement, like the temperance movement and some organisations in the Christian youth movements, such as the YMCA and YWCA, was influenced by British and especially American currents, more than by trends from mainland Europe. From 1871 on this influence inspired the rise, expansion, function and goals of the different Danish women's associations. A few working-class women were active early and slowly through women in labour unions from 1901 onwards they gained increasing influence. But, in general, it was the educated and middle-class women, who dominated the movement up to the young 'Red-stockings' of the 1970s. From the very beginning, it was the long-term goal of the women's movement and its 
branches, periodicals etc. to gain the same social rights as the men had. The rights comprised political and legal equality, economic rights to a fair working income and its disposal, as well as the right to engage in private business and have disposal of inheritance and finally to strive for equality concerning parenthood and children. These aims were to be attained especially through education. In co-operation with liberalminded men in the labour movement and the liberal middle-classes, most of these visions were realised by a variety of means and were implemented step by step over the generations up to 1970, as new goals were put on the agenda. In general, patience combined with stubbornness, organised professionalism and the long march through the social and economic institutions yielded results for women - first with the gaining of full political rights and education for middle-class women, which with time spread outwards and downwards in society to the benefit of all women, regardless of class.

Much of the societal disintegration in the Western world, beginning in the 1960s, exploded in Denmark in the 1970s in a variety of new feminist initiatives. These were expressed in new forms of horizontal and deliberately non-centralised and non-pyramidical women's organisations - often with strong anti-male tendencies and especially disrespect for the forms of the earlier women's movements and their achievements. Women became the majority among students in many areas, went in greater numbers into politics and entered the civil service and the world of business. Today, in the third millennium, 90 per cent of Danish women are now out in the labour market, the highest percentage in the world. But, on the other hand, they definitely do not have their fair share of seats in municipal councils and in parliament, of senior professorships at universities or of the top posts in the world of business etc. Women stop at the middle level under the executive rank - what is wrong? Are the well-educated women deliberately kept out by the male brotherhood? Or do they not want to pay the price of suspended motherhood? Or do they not want to give up the prolonged status of being single too far into their 30s? The committed red-stockings of the 1970s have dissolved their horizontally structured movements - and nobody has taken over. ${ }^{43}$ What is left of the traditional activities of committed women is found in remnants of the old organisations or in the immediate neighbourhood, such as in kindergarten committees or in the activities of their children's private schools.

Perhaps some of the female winners should have joined hands with the above-mentioned old union leader in 1990 and said "Yes, we have been victorious - all the way down to hell", cf. note 60 .

Old Grundtvig should not be forgotten here. In August 1848, when it was clear to everybody that democracy was on its way to realisation, he wrote his well-known programme for a new folkeligt i.e. (popular) 
Denmark in a song where in the last stanza the final words are: ${ }^{44}$

Neither on the battlefield nor at the thing ${ }^{45}$

Shall children and women be disrespected,

Whatever goes up and down

Danish is at all times and in all places love ...

\section{People and nation - relation of identity and of a value basis}

Nationality is the national aspect, understood as a collective and an emotionally loaded consciousness of the mother tongue and the fatherland. Communality and nationality do not exist and cannot be without:

- a people to bear this consciousness, to contain this communality and through action to make it a reality, which again only has meaning and historical existence manifested as a reality in a geographical space, in a history and in a language within a given area of land with its accompanying nature and weather conditions in the case of

- a country, Denmark, which, in the understanding of itself and of other countries, was and is acknowledged as being such and as having

- a temporal and connective history of its own, even if this history be mythical, unscientific and strongly queried by others e.g. Swedes and Germans, and

- a common language, Danish, in which the individual and people together were and are able to think and to express themselves mutually in a common written language and a commonly understood spoken language - with great respect for the dialects - in the domains of poetry, law, politics, daily life etc. and in all aspects of human life in

- cultural and religious forms of expression in common practice and custom, from birth to death, in festivals and daily life, for young and old, which expressions are easily recognisable and widely accepted and steadily discussed but nevertheless have a common value basis of something about Danes, Denmark and Danish.

Meanwhile people and 'Danishness', as well as a number of smaller central concepts, were and are nevertheless characterised by and historically grounded in the above categories. But if people and 'Danishness' should and will go up into a higher unity, the Danes might thus accept and, as members of society, work actively for the maintenance, spreading and implementation of these concepts, i.e. that the Danes might not have them only as external signs but might absorb them internally and be activated by them as an inseparable part of themselves and the way in which they exercise their humanity. 
Thus the understanding is moved from an externally observable programme of self-understanding to a qualitative appreciation of a philosophy of being. To be a part of the Danish people was and is not only to have a passport and citizenship as well as obeying the laws and following the external rules of the game, but indeed as much as living with, feeling for and actively being effective in this qualitative community of values - each individual according to his or her ability and possibility.

There is this significance in the historical background for a qualitative understanding of people and of 'Danishness', both of which form part of and are socially implemented through popular movements.

\section{Social and popular movements - an explanatory concept}

In a series of Anglo-Saxon inspired sociological understandings there is consistently talk of 'social movements', understood as an interaction between comprehensive intellectual currents and correspondingly collective patterns of action in the wider strata of society. These social movements are brought about by and primarily aimed at particular and, more often than not, newly arisen social conditions and the interactional understanding. In short, they are types of protest movements. These are described generally as having a horizontal structure and little organisational solidity amongst the band of followers and are like a force of a relatively short-lived significance, which aims to change society in certain areas, yet not in general. Within a short space of time they can achieve considerable attention in the media and in parliamentary politics by effective action, but normally have no lasting significance, except for the future lives of a few committed participants. ${ }^{46}$ For example, in Denmark and extensively in the Western world, the anti-nuclear movement of the 1970 s and the anti-Vietnam uprising are considered to be such social movements.

The concept of popular movements, used especially in Denmark and in some parts of Scandinavia, certainly hangs together with a qualitative meaning of the idea of people (folk) in such a way that not all social or ideological movements were or are in themselves popular movements, even if they may become such when a social movement grows stable and long-lasting and finds itself to be Danish and national. The qualitative concept of a people with clear and distinctive characteristics, here specifically as the Danish people, is something of which the individual and the community have partly a more unstructured awareness, and of which they become partly very conscious during a lifelong - indeed, a century-long - process and struggle so that at the very end they are willing to defend it even with 
their life as a contribution.

For Grundtvig the peasant-farmers, small landholders and craftsmen working with their hands and a few schoolteachers, pastors and poets, in general from the agrarian sector - working with their mouths, with words - stood out as the healthy core of society. Through a lengthy process of awakening and being helped along the way by such institutions as folk high schools and popular writings, those commoners ought to and could become the Danish people by assuming a national and social responsibility. The new industrial proletariat, which Grundtvig had observed, especially in England, but had also found in Copenhagen's shipbuilding yards, was for him often humanly demeaning and led away from and out of the possibility of being responsible members of society. ${ }^{47}$ Moreover, he thought that the middle-class citizens and academics of the urban sectors, especially in Copenhagen, were not and could only with much time and hard work become a positive part of this qualitative 'people'.

It was only in 1892, 20 years after Grundtvig's death, that the labour movement really gained momentum and not until the 1920 s that it took on the responsibility, not as a mere party of the working class, but as a social force for the whole of society in co-operation with other groups, especially the small holders' Radikale Venstre (the Radical Left Party, cf. notes 47-48).

\section{Peasant-farmers, small landholders, workers and popular move- ments}

Historians have often spoken of 'farmers' movements', ${ }^{48}$ understood as the rising involvement from the 1840 s of the old agrarian peasantry in the affairs of society in defence of their own special interests. Between 1840 and 1900 the peasant-farmers were often acting consciously:

- against the urban dominance in the national and the local arenas, partly in the provincial towns but especially in Copenhagen,

- and partly acting more on the basis of class interests against the urban influence of the academics, urban officials and financial upper bourgeoisie,

- and in the agrarian sector acting on the one hand upwards against the land owners, their social superiors, and on the other hand acting downwards against their farm-hands, their social inferiors, who came from the class of smallholders and the cottagers.

Although a few individual cottagers and smallholders became wellknown in the early years of the farmers' movement, it was really from 1820 onward that one hears of different branches of movements 
amongst the farmers on both a local and on a national level. At first it was on the religious, political and patriotic levels, promoted by the wars of $1848-50$ and 1864 , and then on the economic and financial levels (insurance, credit-unions); later it was on the culturaleducational levels: folk high schools, free schools, left-wing press from the 1860s and community houses and mission houses from the 1880 s; and finally it was concerned with economic production with the whole co-operative movement and economic distribution through cooperative stores etc. from the 1880 s.

From about 1900 the small landholders and cottagers at first seriously followed in the footsteps of the farmers with ideological and organisational as well as economic and political initiatives, while defending and developing their own social interests. Through a successful alliance with certain groups of schoolteachers and academics from 1905 they grew politically as the party the 'Radical Left', ${ }^{49}$ and now the small landholders, as a social class with a conscious sense of their common interest, became a popular (folkelig) movement in a more qualitative sense.

The urban industrial workers and the class of lower functionaries, who were growing in number at that time, were becoming successful and were organising the collective potential of the workers and wageearners in Copenhagen from the 1880s, and then, from about 1900, throughout the whole country through the trade union movement and Social Democracy as well as through the workers' press and many cooperative undertakings. First on the local level and then on the national level, the workers from about 1900 were becoming a movement, bearing a sense of common social interest and being able to change society in the sense outlined above. Such an urban development of the labouring class lay naturally beyond the farsightedness, even of a person, such as Grundtvig with his agrarian horizon. After the First World War the workers' movement was in this broad and socially constructive sense a popular movement - but at the same time a traitor to the proletarian movement as a revolution, as seen from a Marxist point of view, cf. the sources referred to in note 40 .

\section{Social movements as an expression of protest}

Social protests - such as the riots over the bread prices in Copenhagen in 1847 and most of Europe, repeated uprisings, such as the antiJewish riots around 1820, the destruction of machines amongst English textile workers about 1800 or the anti-nuclear movement from the 1970 s - were all presumably expressions of a common anger and were quite serious at the time, but they did not possess a forward-looking constructive perspective, which was more deeply able to transform society. Hence they were rather social or ideological protest 
movements - like many social movements of today - but not popular movements in the sense outlined above. For that purpose they lacked a developmental tendency, which forms and bears a sense of community and a common will expressed over a longer span of years, with the ability to maintain and to implicate something more than relatively narrow circles and interests.

Since institutions and firmly established organisations produce a great deal of useful source material, which often can be processed by computer, there has been a tendency amongst researchers in the social sciences up to the very present time to over-interpret the historical and contemporary significance of institutions and organisations as bearers of social and institutional 'power'. On the other hand there has been a tendency to undervalue the significance of the more sensitive cultural and ideational aspects of individual and collective philosophies, convictions, ideologies and religious views, which often have been expressed in popular and social movements. ${ }^{50}$ The harsh 'view' in social and historical disciplines concerning social and cultural reality and with the choice of interesting fields of research and strategies has, since about 1990, been crucial in a retreat into the past in preference to a more complex and multivariable approach.

\section{Commentary to Figure I (see following pages)}

The time-line from about 1800 runs from the left across the two pages to about 2000 .

There were three principal popular movements in Denmark, which stood out from about 1820 constituting Phase I: the Grundtvigian, the Inner Mission and the workers' movements - whereas other movements have been purposely omitted for the sake of clarity, in any case they often followed similar patterns, see Diagram I above.

All the movements are depicted here by their organisational and institutional derivatives and are entered as circles, ovals, squares, rectangles, triangles etc. in a network comprising Phase II from about 1860. However, the indicated inner splits amongst the religious groups were already occurring before 1850 .

The propagation of new groupings, occurring from about 1880/90, constitute Phase III. About all the clubs and institutions experienced the growth of new sub-organisations by a process of propagation (e.g. women's organisations and youth work) and institutions (e.g. free schools from folk high schools, scouts from YMCAs etc.).

The religious movements maintained their loose and unstructured form (e.g. there were no central registers of members) with the main emphasis on an ideologically inspired dimension. Until 1900 its dominant field of activity was in the agricultural sector of society, while the practical work was carried

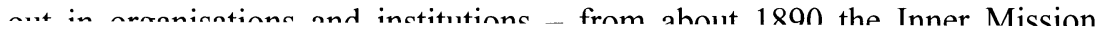


became very effective in the workers' districts in Copenhagen and one or two decades later in the provincial towns.

The workers' movement was, unlike the religious movements, strictly organised from the beginning both locally and nationally, partly because of greater economic and political counter-pressure. It was thus of a more stable structure with its main emphasis on the urban sector; organisationally in the trade unions, politically in social democracy, culturally through newspapers and a system of evening schools and co-operatively through business ventures such as breweries, bakeries, wholesale societies etc. - a special type of workers' sport was introduced between 1910 and 1920.

A country of associations typifies Phase IV, with the nation-wide mass organisations, as we know them from about 1910 to 1970 , and still partly have them in the concept of 'Denmark - land of associations', which has become generally accepted and professionalised, but the diminished ideological consciousness and great distance from top to bottom (note 60) have often been a considerable problem.

Movement - club/association - institution is the pattern that has arisen; the more permanent clubs and institutions have been interacting with each other and had their origin in the more loosely structured movements, which were also more committed to specific issues. The movements themselves can float on further as more loosely structured contact forums and sources of inspiration after particular clubs and institutions have been dissolved. Consequently the class of managers from these transitory clubs and institutions, in accordance with their time, place and particular interest, can be important inspirers and spokespeople for new social initiatives. It is to be noted that the more permanent clubs and institutions are to be considered as not being identical with the specific movement, which inspired their origin, but instead are each an expression of the movement, which can both change and preserve society. 


\section{Figure I}

Signs and abbreviations in alphabetic order:

Co-op/Co, the cooperative village store, now often the last remaining of a cluster of local cooperative enterprises.

Dairy, the farmers and smallholders erected 1,400 collectively owned and run Dairies, the backbone in the milk industry producing products to export.

Free, as in free-school - free-church etc., i.e. private and run by the parents, the congregation etc. and free of state control.

$I M$, short for the fundamentalist religious Inner or Home Mission (1854/61).

$I$, institutions; when village life reached a certain level of specialisation, certain of its activities were voluntarily formalised as clubs with regulations, chairmen, regular meetings, etc. These typically evolved into institutions which, over a more or less substantial period, maintained relevant facilities in owned or rented premises.

$M$, very informal meetings of the locals in open air or in the local M-house. M-house, meeting house or Community house, one for Inner Mission and one for Grundtvigians and in railway towns perhaps one more for Labour.

Newspapers, each of the 4 major parties had 1905-1960 a local newspaper. Sav.bk., savings bank, local and private run bank with mutual responsibility. Sch., school, Denmark had and has compulsory education and often both a public municipal sch. and a private "free" School is to be found in the neighbourhood (i.e. free of state control).

Un., trade unions for the workingmen, with sports, evening classes etc.

Youth, youth organisation often connected to IM (YWCA) or the Grundtvigians (sports and gymnastics).

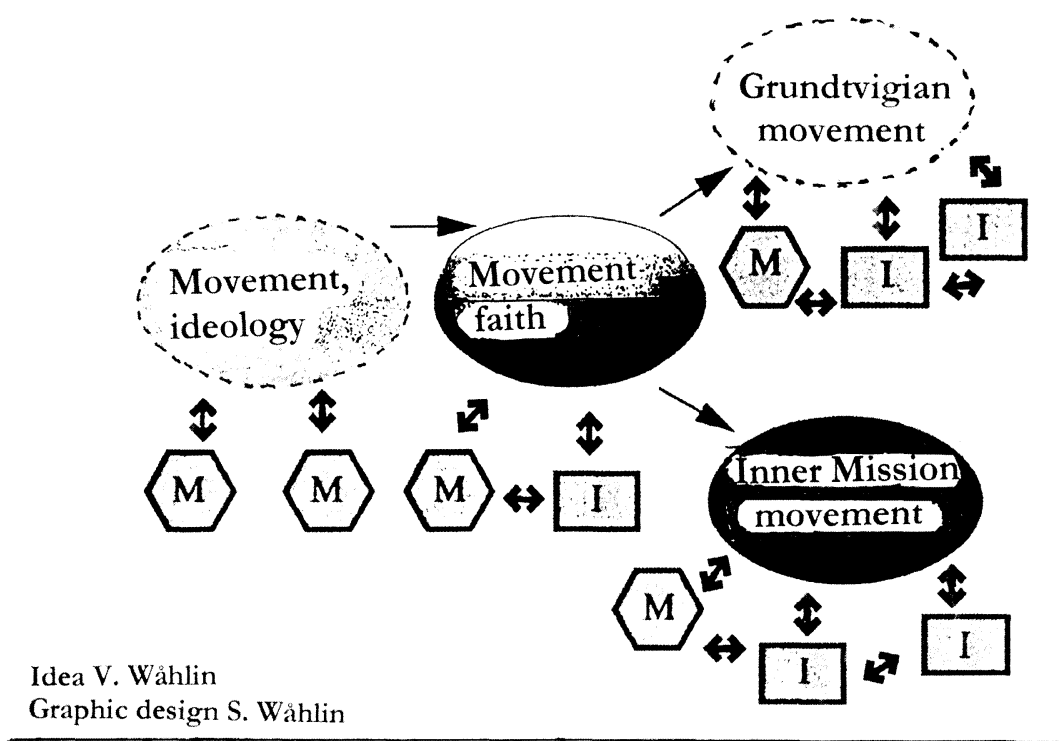




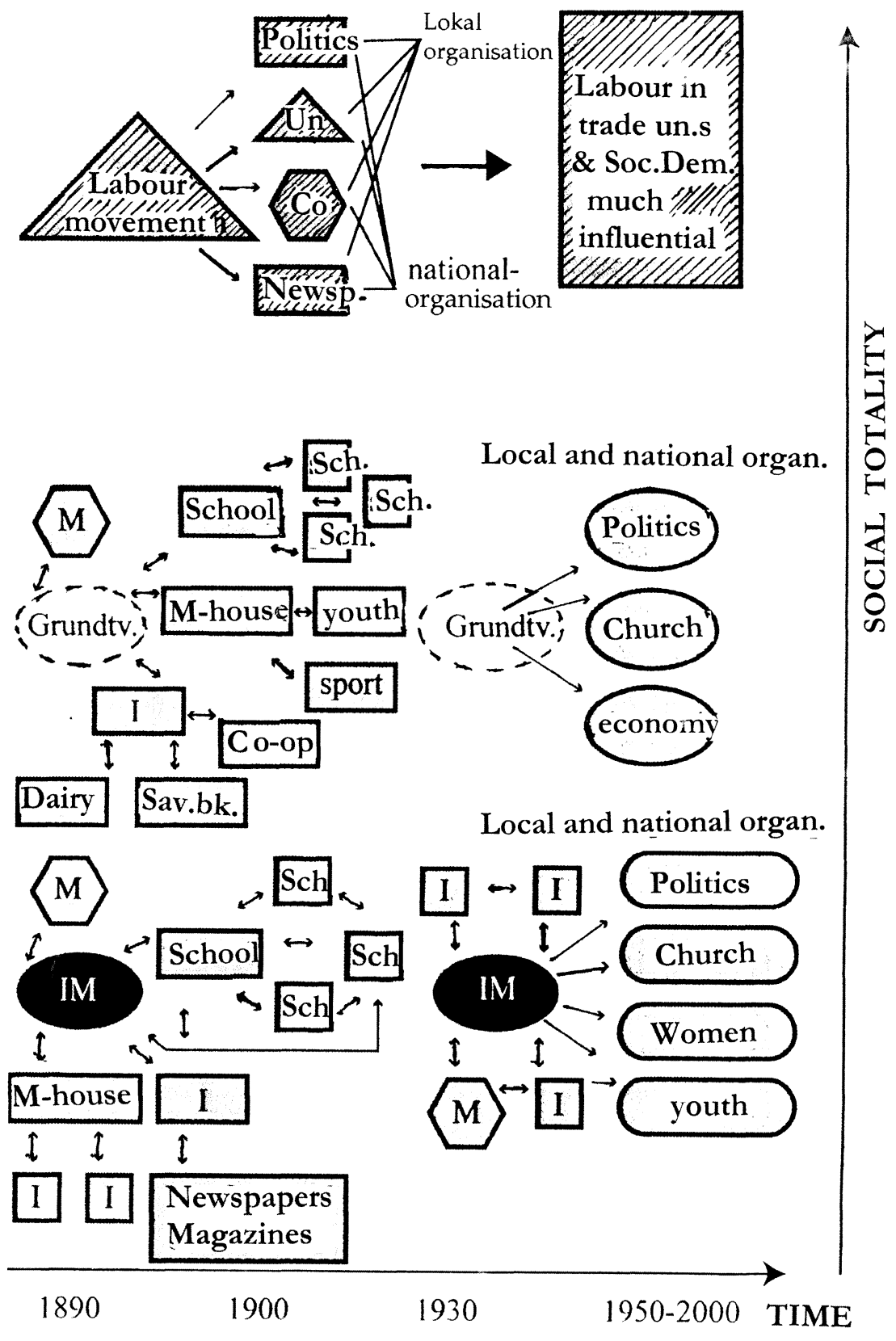


Movement, club/association, and institution: Christians, workers, athletes and patriots in organised behaviour

Despite sliding changes in social practice, there is in Denmark an essential difference between a popular movement and its organisational and institutional manifestations, as depicted in Figure I.

For more than 150 years the heirs of the first popular religious stirring in the Grundtvigian movement and in the Inner Mission have demonstrated a capacity to cope with the practical circumstances of the meetings, the associations/clubs and the more substantial institutions, which were established and developed in local areas without a more permanent national organisation - not even a central membership register exists or has ever existed. In practical terms, it was a question of coming to grips on the whole with meetings to take in hand both patriotic and Christian elements in order to influence young people, to set up free schools and folk high schools and to encourage such movements collectively to publish papers such as Indre Missions Tidende (the Inner Mission's Newspaper) or Højskolebladet (The Folk High School Newsletter) and common song books such as Folkehøjskolens Sangbog (The Songbook of the Folk High Schools) etc.

The leaders and mainstays of these organisations and institutions in their turn had a retroactive effect on the movement in a lively interaction, but they did not develop a movement dominated from above - despite the impressive activities and bearing of a N. F. S. Grundtvig or a Vilhelm Beck of the Inner Mission. When subsidiary organisations or specialised institutions were or are no longer ideologically or practically viable on a local or national level, they have been forced to close, even if with deep regrets. Examples of this are the folk high schools' eternal struggle for existence and the many hundreds of closed mission houses throughout the whole country, which have not necessarily resulted in the movements having disappeared as religious or ideological currents in the population. Movements have their time - they shoot up, blossom and wither away. Some examples are:

The non-class based movements: (I) The temperance movement (cf. above), once a wide-spread institution, has experienced a dramatic decline from about 10 per cent of the population $(200,000-300,000)$ being involved at the time of the First World War to only a shadow of a few thousands being left today; and (II) the women's movements from 1871 until today have not become such mass movements as the labour or sport movements mentioned below, except for the Women's Trade Unions and the early Voting-Rights Movement. But if smaller in number, they have obtained solid and lasting results for all women 
through organisational skill, patience and co-operation with other movements as well as with liberal and farsighted men. The more loosely organised efforts of their grand-daughters and greatgranddaughters, the 'Red-stockings' of the 1970s, also obtained results, but have not left a lasting structural heritage as in the pattern of influential movements with organised forms of expression and institution.

The workers' movement has been deeply affected by a 'deideologising' and the also negative aspects of the effectiveness of the different organisations, known as 'union-fossilisation' and the current great distance between the floor and the ceiling in trade-union organisations and political Social Democracy. These factors have almost stifled the solidarity and the social idea in the old workers' movement, cf. note 60 . The influencing of opinion by the newspapers and of common politics by the party and the trade-union movement are still visibly present in the everyday life of the workers of today. But currently, in varying degrees and not as uniformly as in former generations, Social Democracy has, to a large degree, become a party of the middle middle-class and of groups of functionaries, but these groups like all others seek the middle position as well, while the remaining 'real' workers in the field of production have gone mainly to the nationalist Dansk Folkeparti (Danish People's Party, note 9).

Physical culture, in its widest sense of the word, has its background especially in the movement of the national shooting clubs in the 1860s and was introduced into the folk high schools and the few upper-class boarding schools as gymnastics and athletics at an early stage. ${ }^{51}$ There it became an important part of the popular element of the curriculum and of the formation of an identity in wide circles of the population, both rural and urban. From the 1880s one can speak of an ideological struggle throughout the country, but especially in the towns, over the German-Danish dichotomy between the military inspiration in physical training and the victorious Swedish Ling system of gymnastics until the break between the shooters and the gymnasts in 1929. From the 1890s on, physical culture expanded, not just in the folk high schools and similar institutions but all over society to include football and all forms of athletics and sport, and has since then become the most inclusive of all popular movements, according both to the size of its membership and to how widespread it is in all social sectors. Physical culture has appealed to all age-groups, but has currently been able to attract especially young people and has continually been involved in an interaction with other branches of popular movements e.g. from a natural place in the folk high school to a special form of athletics for workers and the sport and athletics departments of the YMCA and YWCA, etc. The specialisation of top athletics and the internationalisation of the competitive element from the 1896 
Olympics and since that time have not substantially altered the widespread popularity of athletics. Despite massive popular support, e.g. in halls and such like, the principle of voluntarism and the local leaders' commitment on a non-wage or non-profit basis have been and still are a central element in the nature and the effectiveness of physical culture in Denmark.

The patriotic and national aspects of the democratic element have been absolutely essential as stabilising phenomena in the Danish social development in engaging broad social groups, both ideologically and organisationally. This has occurred over two centuries and, moving with the times, they have very often interacted with the movements and their organisations and institutions, already mentioned above. But it has been on the very local level especially that many of these nationwide phenomena have come and are coming to the most concrete expression in the consciousness of the individual and the group. In attitudes and patterns of behaviour concerning our private free church, our mission house, our football club, our private free school etc. we find this local identity strongly expressed, where again 'free' means free from state control. All the Danes of today do their weekly shopping cheaply in chain-stores, but we all take notice if 'they' want to shut our local co-operative store, ${ }^{52}$ even if we have economically strangled it through our lack of customer loyalty. So our local loyalty to the remnants of the popular movements often coincides with our day to day pattern of behaviour as consumers, and the same with our national preferences of Danish agricultural products. It was nearly unthinkable 25 years ago that a Danish housewife would buy anything but Danish butter, but today the author of the article often has German export butter in his refrigerator.

\section{Interaction between local material conditions and ideological and religious protests}

As in much of the recent research in the field, ${ }^{53}$ I accept that essential changes in the patterns and conditions of production in society, such as the agricultural reforms from 1788 to 1814 and the industrialisation from the late $1800 \mathrm{~s}$, were most significant for the fact that old, but revitalised or totally new religious and philosophical currents amongst the population can make a second and more than sporadic impact, which again transforms society as such. Yet, I am not pleading for a simplified materialist reductionism of superstructure and basis, but the opposite. It is not determined beforehand which magnetic individuals and which religious currents may fulfil the new conditions of possible growth or may fail to respond, but they must be clearly investigated in each individual case. The central issue was and is that each given form of state or economy with its relative patterns of culture, religious 
traditions and specific ways of reaction to the winds of change will reach situations, where the inherited or structured social and cultural patterns of reasonably practical and ethically defensible modes of thought and behaviour are no longer adequate. This brings with it an experience of being rootless and an inability to act amongst many members of society, which is often described in the source material as an abysmal feeling of $\sin$ and betrayal. This type of spiritual depression made and still makes people in certain situations open to a new ideology or to a renewed religion, which will once more allow the people involved to act, to live and to take an active stand on the deeper problems of life and of practical daily living.

We can first point out among those people seeking renewal a protest against the existing conditions on the religious or ideological level in a stage of mental awakening and religious revival, often with a strong feature of condemnation of others. But, depending on other things such as strong leading characters, charismatic figures or leadership from a smaller, trend-setting group, we can subsequently observe more forward-looking and socially constructive initiatives - as depicted in much of our literature of the last 150 years.

At the beginning one has, therefore, no definite knowledge of where the local and less extensive popular current will ultimately go, viewed from the religious or political-ideological angle. It has no permanent structures, but is rather a network of like-minded people with a loose system of meetings, which range over perhaps more than a decade and which, on the social level, attract people principally without any respect of persons, but mainly from the middle and lower classes.

New religious currents rarely attracted people from the lowest social group, the real local proletariat which comprised between 15 per cent and 25 per cent of the population; likewise many from the local élite stood back, perhaps with the exception of the pastor and school teacher. A more permanent organisation and a stronger collective consciousness were and are promoted partly by inner forces among the believers and partly by the possible opposition of the surrounding community in the well-known 'they versus us' effect as seen in the 'martyrdom' aroused by stiff-necked pastors, as was the case in many instances. ${ }^{54}$ Organisational structures are also partly promoted by the fact that a leading religious and organising figure or a narrow leading group arose out of the situation from either an internal or an external impulse, a leadership which could or wanted to lead those connected out of an often threatening self-destruction or total withdrawal into a 'turn your back on the world' mentality and instead offer a new perspective on life.

According to the source material, many similar more loosely structured associations appear to have retreated back into themselves 
for a period or even permanently. It can be pointed out here that many local leading figures and pastors sensed the situation and quietly gave way to some extent in the direction in which the wind was blowing. What was the man in the street to do locally with all that bother and discord, which people from other places knew would follow in the wake of an organised religious opposition? 'Yes, but when now both the pastor and the parish clerk and the important people have mended their ways? No, thanks, not with us, it will still go on!' We can sometimes find something of this sort in the reports of emissaries from the pietistic stronghold of Christiansfeld ${ }^{55}$ and from the early Inner Mission colporteurs. ${ }^{56}$ In other cases, the necessary leadership and structure for more lasting and meaningful initiatives were not found nor did they arise. But in those cases when it did not lead to local conflict or to lasting organisations, one can seldom find any profitable source material, so we do not know anything about that which left no traces, nor shall we ever be able to know it. All things considered, we shall probably have a tendency to overvalue conflicts and to undervalue the possibly many places, where people coped well as they went on along the road. With the first attempts, the quiet and modest initiatives prepared the way for the next generation's broader growth in forming institutions from the 1860 s on with private free schools, folk high schools and savings banks etc. and from there further into the society of the $1880 \mathrm{~s}$, typified by its organisations and networks of interacting movements and associations and organisations - so that we in Denmark 100 years later are still living in the effects of this organisational boom of the years 1880-1914.

\section{The state, market economy, modernity and popular movements}

Traditionally in Denmark the classical tasks of the national government and of the municipalities (local government units) were the taxation system, the police and legal system, defence, the central and local administration, economic legislation, the church etc. But from about 1800 the state and from the 1840 s the municipalities took control of a general modernisation and an expansion of a number of necessarily structured institutions in society, such as fire insurance, education, the road authority and transport, social welfare, health, building regulations etc. Whereas those authorities controlling the public sector in some other countries during the $19^{\text {th }}$ century, and even into the $20^{\text {th }}$ century, did not want to regulate (such as in England and the USA) or they could not control the social and economic development (such as in pre-revolutionary Russia), but left too much to social chaos or privately organised forces to structure.

Into a triangular relation between the simple citizen and the public sector (i.e. the state plus the municipality) along with the de-restricted 
market regulation of the economy, the popular movements with their efficient institutions entered as a mediating layer, which both protected the individual and was collectively powerful in its ability to change society. For this reason, the popular movements contain both reactionary and forward-looking potential in relationship to social development and, as well, the protective and preserving traits as socially constructive features also currently develop in a continuous interaction with other social factors and developmental tendencies such as:

Figure II

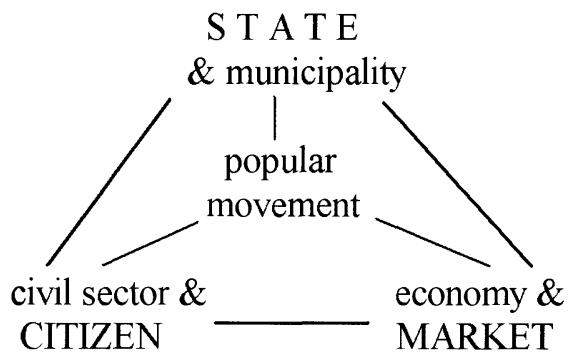

According to eyes that see and the questions that are posed, researchers of the present can and observers of the past could find both positive and negative traits in the specific forms of organisation and spheres of activity of the popular movements. But no serious observer can deny that the popular movements have been and, in a way, still are essential for the specific Danish development and are also a means of understanding this development.

\section{Movements, volunteers and social coercion}

The strong modernisation of the state from above and the breakthrough of the coming organised capitalist market economy from outside from about 1840 contain each in themselves and in interaction with each other strongly organising elements for the individual person and for larger groups by direct coercion (such as the worker at a machine, who is forced to follow its rhythmic motion) and partly by indirect coercion (such as the farmer against the bank and the bondholder). For this reason the principle of voluntarism was and is so important for the popular movements. Even if many people really experienced and, especially in our time, experience such phenomena as workplace agreements and 'closed shop' of the trade unions as being very oppressive, then this element of force lay and still lies more on the organisational level than on the level of the movements and of their ideology. Inevitably, each and every member of society must 
acknowledge the power of the state through the administration, the police, the judiciary, the legal system and the taxation authority etc. or pay a high price for stupidities in relation to the power of the state.

Coercion and the system of workshop agreements were and are an expression of the asymmetrical power relationship between the individual wage earner and organised capital, expressly displayed in the employers' economic activities. If the worker wanted to participate in the football club Frem (Forward), in the workers' funeral fund or subscribe to the Social Democratic paper, it was totally a voluntary choice for him to decide. In addition, it was a voluntary decision for a freeholder to belong to the Lutheran and Grundtvigian non-state 'free' church, to place his children in a private 'free' school, to let one savings bank in preference to another handle his money or choose the grocer in preference to the co-operative store, as long as he paid appropriately. ${ }^{57}$ But a political freedom to choose, a definite goal of social and cultural freedom and a minimal economic freedom were and are connected - it was easier for the freeholder to choose freely from amongst the possibilities presented by society than for the agricultural labourer. It is similarly easier today for academics in the social middlerange to make choices from the possibilities, which are presented by Danish society, than for second and third generation immigrants in the ghetto-like Aarhus West (Gjellerup Parken), even if the academics are unemployed. $^{58}$

Let us take the Inner Mission women as an example of organisational manifestations of the popular movements. Around 1900 they held bazaars to support either the mission in Africa or the Magdalene Home for 'fallen girls' in Copenhagen. The voluntary commitment was a key element in such activities, even if a certain amount of social pressure could be exerted on individuals to contribute to the 'good cause'. If we look currently after 2000 at the Inner Mission, YMCA, YWCA and Kirkens Korshoer (the Church Army), ${ }^{59}$ and their many opportunity and second-hand shops or at the whole range of voluntary leadership in young people's organisations, in sport and athletics, both on the local and national level, it is the principle of voluntarism, which is fundamental. The state, but particularly the local municipalities, often make their own contribution to the outer administrative framework of the popular institutions with cheap rents or premises and investment to make possible the social activities; but life in the extensive activities of the clubs would not function without the voluntary leadership and band of workers. Voluntary organisations were set up like this 150 years ago and they are still functioning in the same way, in the broadest sense of the work of Forenings-Danmark (Denmark - land of associations). 

institutions

Generally, I consider that the institutions and the more permanent organisations were and are in a continual and fruitful interaction with the ideology and looser structural form of the popular movements in order for them to cope with definite local and national needs, conditions and problems. The tightly structured initiatives are not the kernel of the social potential of the movements, they are not the head which looks forward and which thinks, feels and transforms the potential into visions, but can rather be likened to the limbs which carry out the work of the visionary.

When the spirit and a certain common ideology disappear from the movements, their capacity and significance in the structuring and changing of society will cease to exist after a shorter or longer time; just as the institutions founded by them will continue on as empty shells without any capacity to create new life with inner growth and outer propagation; as illustrated in Figure I. But some organisations have become so 'hotted-up' and effective to be able to cope successfully in modern society so that, after being freed from their original ideological commitment in the specific movement, from which they started, they either create or find for themselves new goals and tasks. Thus, the survival and activities of the organisations have become an object in itself, such as the reconstruction of old buildings, which are now used for totally different purposes. On the southern island of Lolland the author has seen a former mission house, which has undergone alterations to become a local swimming pool; in the northern city of Ålborg there is a former 'free' church with a tower and the lot, which is now an IT business; the old YMCA stronghold in Rosenborg Street in central Copenhagen is now the home for the Department of Sociology of the University of Copenhagen etc. One of the former leaders of the Danish trade union movement - who himself had been criticised for dictatorial behaviour - warned, as mentioned above in the 1980s, against the fossilisation of the popular organisations to Labour's own destruction. ${ }^{60}$

If institutions with an originally popular background still have a necessary social function, but can no longer obtain the essential funds, voluntary workers and modern equipment from voluntary or private sources, we see them either shut down or absorbed by the public sector and budget-directed logic. After the takeover by the public sector, the originally compassionately committed volunteers with a normally strong sense of calling often unfortunately assume - slowly but surely, and quite conscious of the fact - the pure wage-earners' mentality of both trade unions and the public bureaucracy: 'do this, do that' according to a stipulated time and wage, as the programme of ration- 
alisation determines. Those who formerly had a strong sense of calling have been deprived of their own initiative and commitment to work with falling productivity, sinking quality and lacking compassion in their work as a result. Every reader can almost daily find examples of this development in the newspapers, really a retrograde step, indeed it is a matter of regret to the consumers and fellow-workers and to the detriment of society as a whole. On the other hand, these negative results become equally a matter of surprise and of irritation for the public bureaucracy and the politicians, who believe in balancing budgets and who are constantly amazed at and cannot grasp or learn the fact that human and social realities do not conform to their little speeches on the TV screen or the logic of the production-line.

When such a 'development' - or rather transformation - is brought to an end, the original and socially constructive link with the common people (folkelighed) and responsibility to fellow humans behind the initiative have been lost or have had their day. An old battle-song from the workers' movement says 'Let them fall, who cannot stand' and of course Old Grundtvig himself believed that 'life is in struggle', where there are not only winners but also losers. ${ }^{61}$

\section{From the popular movements of classes to the classless 'so what' of post-modernity}

After 1970 there has been ostensibly no longer a need nor a place for the previously class-based political parties and organisations and their ideological and religious values because of the transformation of production from manual to non-manual work, internationalisation and the Danish women's world-record entry in the working market. But a new orientation is being forced through economic demands and military co-operation within the new world order after the fall of the Soviet Union, as well as the globalisation of everyday life. The same orientation creates a threat facing the almost neglected Danish democratic social and religious values from the ideologically conscious confrontation from small Moslem circles, which attract the attention of the media. This has resulted in a rising attention and reflection in many circles - and a corresponding embracing by politicians of everything concerning the philosophical and valueconscious basis of what constitutes 'Danishness' as far as the broader population is concerned, indeed was and is - such as the workers' former slogan 'Do your duty and demand your rights' or 'The broadest shoulders will bear the heaviest load' etc. Is this reflection only a type of retrospective ritual dance around really dead values during the unavoidable 'progress' of individualistic market capitalism, or it is, nevertheless, something to take into consideration?

We shall presumably see single-issue movements, like those from 
the 1960s keeping on appearing, with their weak structures and loose networks, which come and go. But will they have any lasting and profound influence on social development, as the popular movements have done over the last 150 years and are, to some extent, still doing today? Can there be a forward-looking and optimistic basis, which has intellectual depth and the ability to foster fellowship and which rests on the remains of the interests and movements of the class society in more inclusive circles of the population? If the answer is in the affirmative, then the whole Danish social system, developed over a period of 150 years, is clearly not only the product of the popular movements, but also to a large extent an interaction between the popular movements and other factors of the state and the economy, which influence society ideologically, culturally, politically and economically.

\section{Research on the impact of the popular movements on society}

Research in popular movements in the already stated qualitative approach is central for an explanation of the history of Grundtvig's impact on Denmark and further afield. To understand the distinctive nature of the Grundtvigian movement on the visionary and religious level, as well as its specific social patterns of organisation and ways of operation, we may also recognise its opponents as well as its allies in the established Church of Denmark, in the political world, in national and democratic dimensions, in the Inner Mission and in the smallholders' movement, and last but not least, in the workers' movement. In short, by inclination and pressure of time we have hitherto looked inwards into Grundtvig and the Grundtvigian movement far too long and far too much and have neglected to understand him and the movement's influence outwards in the continual interaction with the surrounding society, in which he and the movement found themselves - in a living interaction.

Perhaps the present article, with its attempt to establish a necessary framework for understanding the popular movements, can be recognised as demonstrating headway achieved towards an explanation of my approach. But at the same time this article and its Diagram I show how massive the task is and how vast the research is, which lies before us, lasting many years. 


\section{Figure III: Popular interaction}

- the complex circle of interaction from a mental current to stable institution

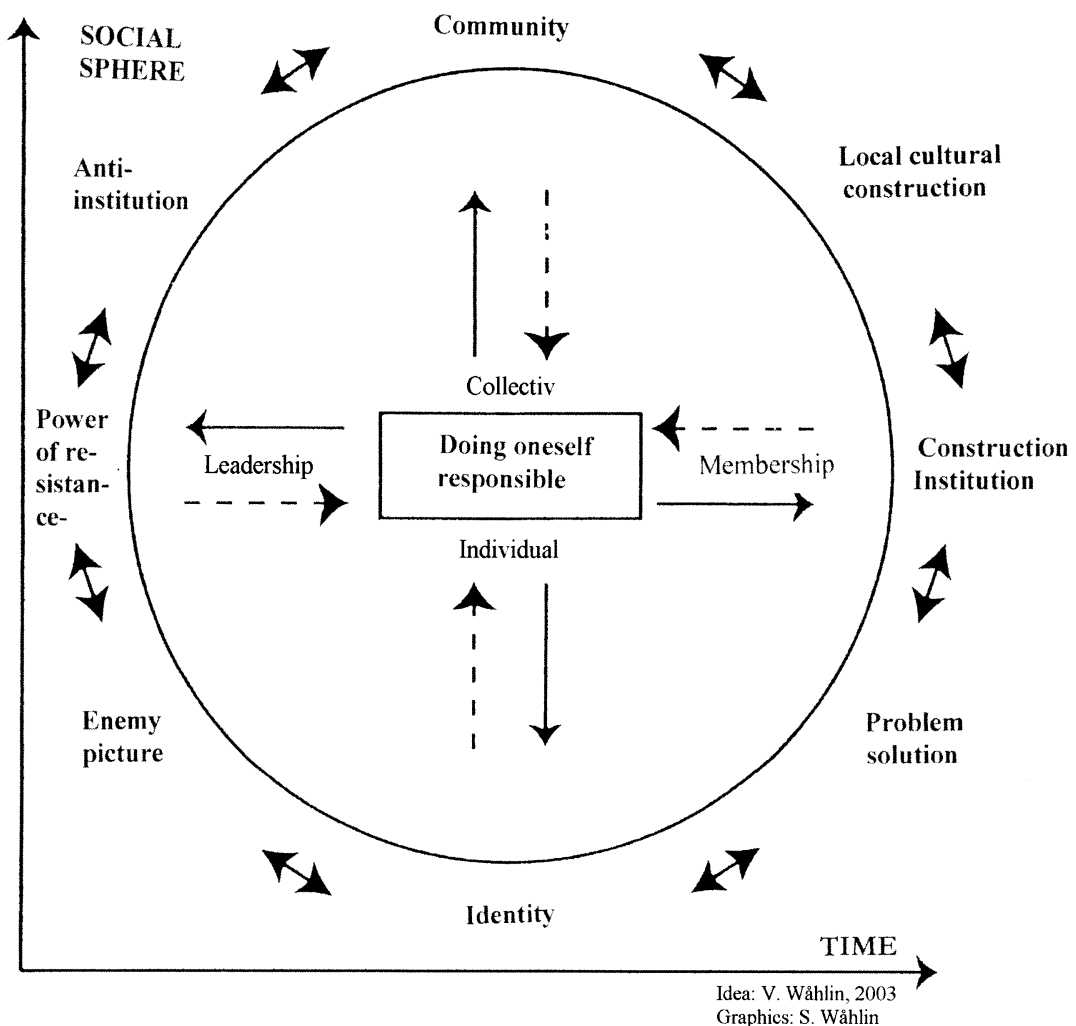

Commentary to the circle of interactions - a model of a social process, which

I. begins as a non-manifest mental current 'against' something that is wrong -->

II. then transforms to a movement where some leaders appear spontaneous or provoked by the reaction from the societal system (someone is doing himself or is don responsible), the movement is then either crushed by force or disappears because of lack of resistance or it gets a broader following due to competent leadership and regular membership -->

III. which transforms into a more stable association or club with more permanent leadership and organisational skills, II+III finally-->

IV. establish more permanent institutions (school, sports club, newspaper meeting house etc.) with professional functions and competences - these may, due to social relevance, even live after the original movement is dead.

Hitherto theologians and literary researchers have left their mark on scholarly studies of Grundtvig and the history of his impact over a broad front. An examination of the articles in Grundtvig-Studier from the beginning until the present fully demonstrates this fact. But in the future more interdisciplinary research will necessarily show the increased attention to the history of Grundtvig's impact. Historians, in particular, as well as social scientists, ethnologists, anthropologists and 
educationalists will no doubt contribute to this development with something of a broader interest in and understanding of Grundtvig and his reception in Danish society in line with the gratifying internationalisation of interest in and research on Grundtvig of recent years.

As an example of constructive contributions from social scientists to an understanding of essential aspects of popular movements, I have presented Figure III, entitled 'The complex circle of interaction'. This model illustrates how a perception of social structure as a key to forms of thought and activity, especially amongst a specific group of immigrants in the district of Nørrebro in Copenhagen in the 1990s is expanded in time, space and complexity - here from an historian's point of view around the central theme in the popular movements: 'we can and we want to do it ourselves'. Certain philosophers and sociologists think that this process is very significant for self-assertion i.e. how individuals and their immediate circle had and have increased influence on the form, activities and future of society. They do so in a dialectical process which also is a learning process and an ongoing and complex interaction, which as a rule begins on the local level, but often is transferred to the national level.

Danish readers themselves can insert the conditions around the first religious revival movements, e.g. the Kerteminde Movement around 1820 and discover how well the model fits there. So it is my guess, that the model has also had a broader significance outside Denmark during the period 1800-2000.

\section{Postscript}

Grundtvig was no doubt the most influential single figure in Denmark of the $19^{\text {th }}$ century, but he was not alone. He was the right man, at the right time, in the right place with the right programme, first for the peasant-farmers and later for the popular movements. The special social conditions of the country with the peasant farmers dominating the agrarian sector during 1840-1960/70 and this sector playing the leading role in national modernisation during the period 1840-1950 made the middle middle-class, first in the agrarian and later in the urban sector, the backbone of society. From 1900 to 1930 the smallholders and the working class and their movements and organisations slowly absorbed and accepted the middle middle-class ideals and responsibilities of the peasant-farmers and their parallels in the cities. Moderation and compromise became the mode of social thinking and action at all levels and in most situations in this country, where there should be a place for everyone who wants to work for and contribute to a 'Denmark for the people'. Grundtvig alone, even with his most ardent followers, would not have been able to give the 
popular movements their societal strength between the state, the market and the citizens. On the contrary, it was the strength of the popular movements that gave Grundtvig his outstanding influence up to this very day on the Danish modernisation in a 'living interaction' (en levende vekselvirkning) to quote one of his favourite expressions.

\section{Danish terms}

Bondevennernes Selskab: the Society of the Friends of the Farmers.

Dansk Idrcets Forbund: the Danish Athletic Association.

Danskhed: Danishness.

Danske Gymnastik- og Idrcetsforeninger (DGI): Danish Gymnastic and Sports Associations.

Dansk Firmaidrcetsforbund: Danish Company Athletic Union.

Dansk Folkeparti: the Danish People's Party is a phenomenon of the 1990s, typical of similar political protest movements throughout the Western world.

Det Kongelige Teater: Royal Theatre in Copenhagen.

Det Radikale Venstre: the small landholders' party, The Radical Left.

Det Skandinaviske Selskab: the Scandinavian Society.

Folkekirken: the folk-church, the national church; the Evangelical

Lutheran Church in Denmark.

Folkelighed: folkelighed and other folk/e connections are inventions by

Grundtvig and now generally accepted in Denmark yet difficult to translate into English, something like 'folkishness' might fit, but here and elsewhere I often prefer 'Danishness'.

Folkelige bevagelser: Popular Movements.

Folket: the people.

Forenings-Danmark: Denmark - land of associations.

Frie købmand: village grocers.

Gjellerup Parken: immigrant dominated dwelling houses at Aarhus West.

Grundtvig-Studier: the leading Grundtvigian annual journal published by Grundtvig-Selskabet since 1948 .

Himmelbjerget: a hill - 147 metres above sea level - where 19th century Danish poet Steen Steensen Blicher organised folk meetings (Himmelbjerg festivals), of which the first was held on 1 August 1839.

Hovedstadens Brandkasse: the Copenhagen Fire Assurance Society.

Indre Mission (IM): Inner Mission and Home Mission.

Indre Missions Tidende: IM's Danish weekly 1861-1901.

Jyllands-Posten: Danish national newspaper.

Kanslergade: the name of the street where at that time the Social

Democrat Prime Minister Th. Stauning lived.

KFUM og -K: Kristelig Forening for Unge Moend (Kvinder), Christian 
youth movements, cf. Young Men's (Women's) Christian Associations, YMCA and YWCA.

Kirkens Korshoer: in the Anglican Church in several countries 'The

Church Army' has a similar function as Kirkens Korshoer in

Denmark exercising broad practical welfare.

Konventikelplakaten: Conventicle Decree. Decrees from the government in the name of the king were made public as placards glued on the walls or read by the priest at the Sunday services.

Højskolebladet: Folk High School Newsletter.

Folkehøjskolens Sangbog: common Danish song book.

Skamlingsbanke: a steep hill near the Danish-Slesvig border, later a national Danish symbol.

Selskabet til Trykkefrihedens rette Brug: the Society for the Correct Use of the Freedom of the Press.

Stcender-forsamlinger: Estates' assemblies.

Tidehverv: a theological and later more popular religious current and a periodical expressing the current from the 1920s directed against the two major Danish Christian movements of the more fundamentalist 'Inner Mission' (Indre Mission) and the more open 'Grundtvigianism' as well as opposition to humanistic currents and organisations and promoting the responsibility of the single individual to God and to his fellow men yet with no hope of salvation of his own but only by God's Grace.

Venstre: the farmers' party, The Liberal Party.

Andelig: much used Danish word which is nearly impossible to translate into one English word - in contrast to material it ranges from 'spiritual' and 'religious' when dealing with the numinous to 'intellectual' and 'cultural' as a psychological and fine art term.

\section{Bibliography}

Just a few non-English references are given in the following bibliography. They are directly quoted Danish source material and references to Danish periodicals and newspapers or books and articles with summaries in English:

Allchin, Arthur M. (1997), N. F. S. Grundtvig. An Introduction to his Life and Work, Aarhus.

_ et al. (eds) (1993), Heritage and Prophesy - Grundtvig and the English-Speaking World, Aarhus.

— et al. (eds) (2000), Grundtvig in International Perspective. Studies in the Creativity of Interaction, Aarhus.

Anderson, Benedict (1983), Imagined Communities, London.

Balle-Petersen, Margaretha (1986), 'Everyday Rainbow: On Social Movements and Cultural Identity', Scandinavian Yearbook of 
Folklore, vol. 42, 27 f.

Becker-Christensen, Henrik (1981), Skandinaviske drømme og politiske realiteter 1830-1850, Aarhus.

Berlingske Tidende (1749 f.), newspaper, Copenhagen.

Borish, Steven M. (1991), The Land of the Living - The Danish Folk

High Schools and Denmark's Non-Violent Path to Modernization, Blue Dolphin, USA.

Borish, Steven M. (1996), Danish Social Movements in a Time of Global Destabilization, Vejle.

Danmarks nationalleksikon, vide, Den Store Danske Encyklopædi.

Denmark. An Offical Handbook (1970). Issued by the Royal Danish Ministry of Foreign Affairs, Copenhagen.

Den Store Danske Encyklopadi, vol.s 1-20 + suppl. (1994-2002), Danmarks nationalleksikon.

Folkehøjskolens sangbog (1972), $15^{\text {th }}$ ed., (the last edition before the many alterations from the 1960 s really broke through in the classical national, Danish singing).

Grundtvig, N. F. S. (1982-1984), Sang-Vark til den Danske Kirke, vols 1-5, 1837-75, 2. reprint 1.1-2, 2.1-2, 3, 4.1-2 and 5.1-2.

Grundtvig-Studier, (1947 f.), (the leading Grundtvigian research yearbook).

Gundelach, Peter (1988), Sociale bevagelser og samfundsforandringer, Aarhus.

Gustavsson, Anders (ed.), (1993), Kulturforskning kring alkohol $i$ Norden: föredrag vid ett nordisk symposium i Uppsala, Uppsala.

Henningsen, Hans (1995), 'Højskole i 150 år - bøger omkring et jubilæum', Grundtvig-Studier 1995, 193-204.

Indre Missions Tidende, Den (1854 f.), (First periodical, later weekly paper of the religious 'Kirkelig Forening for den Indre Mission', 1861-2006).

Jensen, Niels Lyhne and Broadbridge, E., (eds) (1984), A Grundtvig Anthology, Cambridge.

Jyllands-Posten, Morgenavisen (1871 f.), newspaper (now the largest in Denmark), Aarhus.

Kaarsted, Tage and Ole Samuelsen (eds) (1967), chapter 'Kanslergadeforliget 1933', Kilder til Danmarks politiske historie 1920-1939, (Historiske kildehefter [for gymnasier m.v.], Sources to Danish political history 1920-1939), Copenhagen, 109-117.

Knudsen, Johannes (ed.) (1976), N. F. S. Grundtvig, Selected Writings, Philadelphia.

Kristeligt Dagblad (1896 f.), newspaper, Christian Daily, Copenhagen. Kuhn, Hans (1990), Defining a Nation in Song. Danish patriotic songs in songbooks of the period 1832-1870, Copenhagen.

Larsen, Kurt E. (2001), Vilhelm Beck-missionsprcesten, Fredericia.

Lindhardt, P. G. (1951), Grundtvig: An Introduction, Oxford. 
Lund, Birte F. and Carsten Oxenvad (2003), Freedom in Thought and Action. Kold's Ideas on Teaching Children, Copenhagen.

Lund, Jørn et al. (eds) (1994-2002): vide Den Store Danske Encyklopcedi, vols 1-20.

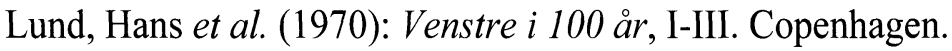

Michelson, William (1968), 'From Religious Movement to Economic Change. The Grundtvigian Case of Denmark', Social History, 2, 283-301.

Mlbs 72 (72): Minavisens lille blodrøde sangbog, Copenhagen.

Sanders, Hanne and Vind, Ole (2003), Grundtvig - nyckelen till det danska?, Lund.

Schultz Hansen, Hans (1998), 'Schleswigsche Identität 1840-48' in Geschichte Schleswigs vom frühen Mittelalter bis 1920, Aabenraa.

Stangerup, H. (red.) (1943-44), Danmarks store Digtere: Dansk Litteratur-Haandbog, II, Odense.

Thaning, Kaj (1972), N. F. S. Grundtvig, Copenhagen.

Thodberg, Christian and Thyssen, A. Pontoppidan (eds) (1983), Tradition and Renewal. Grundtvig's Vision of Man and People, Education and the Church in Relation to World Issues Today, Copenhagen.

Schmidt, Kjeld and Wechselmann, Ilja (1970), Den danske fagforstening. Var der nogen der $L O$, Copenhagen.

Wåhlin, Vagn (1980), 'The Growth of Bourgeois and Popular Movements in Denmark ca. 1830-1870', Scandinavian Journal of History, vol. 5, 151-183.

- (1986a), 'Opposition og statsmagt. Legale rammer og myndighedernes reaktionsmønstre over for de frembrydende borgerlige politik-former under den sene enevælde' in Mikkelsen, Fl. (ed.), Protest og oprør, Copenhagen, 105-130.

- (1986b), 'Ikke stykkevis og delt' in T. Bekker-Nielsen (ed.), Stykkevis og delt, 5 essays om Grundtvig og grundtvigianisme, Aarhus, 9-54.

(1987), 'Popular Revivalism in Denmark, Recent Research Trends and Results', Scandinavian Journal of History, vol. 11, 4, 363387.

(ed.) (1994a), 'Nik. Fred. Sev. Grundtvig, Præst, Politiske Betragtninger med Blik paa Danmark og Holsteen' (1831), Grundtvig-Studier 1994, 16-58.

(1994b), 'Grundtvig i politik op til 1830', Grundtvig-Studier 1994, 59-91 and $81 \mathrm{f}$.

http://www.pladstilosalle.dk/baggrund/persongalleri/29.html [Thomas

Nielsen] 
A Danish version of this article can be found in Grundtvig-Studier 2003, 7-44.

1 The Danish words for the duchies of the Danish realm are Slesvig and Holsten; I have not been able to find any good reason in any dictionary why English-speakers have preferred the German spelling of 'Schleswig' and 'Holstein'. Here I otherwise use the English forms for Danish place names such as Jutland, Copenhagen, Sweden, Denmark etc., which often makes it easier to use Danish maps; the American S. M. Borish in 1991 in, The Land of the Living, 32, 36-37 has followed the same path.

2 I am most grateful to Associate-Professor John Stanley Martin, Melbourne, for the translation of the text and Professor Asoke Bhattacharya, Calcutta, for translation of the footnotes and both for comments on the presentation of this article in a form comprehensible to the non-Danish reader, as I am to archæologist, Sidsel Wåhlin, for drafting the figures and diagrams.

3 Nicolai Frederik Severin Grundtvig (1783-1872), Danish pastor, historian, poet, writer, philosopher, educator and politician was one of the most influential public figures of $19^{\text {th }}$-century Denmark and even still today in the $21^{\text {st }}$ century. While his contemporaries, Hans Christian Andersen (1805-1875) and Søren Aabye Kierkegaard (1813-1855), became world-famous and also have made and still make a great impact on Danish cultural and intellectual life, neither of them ever reached Grundtvig's influence inside Denmark - he is under our skin, in our very soul, whether we recognise it or not. Introductions in English to Grundtvig, which are still authoritative are, Kaj Thaning (1972), N. F. S. Grundtvig, Copenhagen and P. G. Lindhardt (1951), Grundtvig: An Introduction, Oxford; and more recently from an English scholar, A. M. Allchin (1997): N. F. S. Grundtvig. An Introduction to His Life and Work. Aarhus.

4 In general I refer the English-speaking reader to Steven M. Borish, The Land of The Living - The Danish Folk High Schools and Denmark's Non-Violent Path to Modernization (Blue Dolphin) 1991, ISBN 0931892-62-7 and the references in English there and to his later book, Danish Social Movements in a Time of Global Destabilization, Kroghs Forlag, Vejle 1996, ISBN 87-7469-953-9. In order not to overload this essay with references in the already extensive number of notes, I have omitted sources in Danish, but a few central books and articles in English are: A. M. Allchin et al. (eds), Heritage and Prophecy - Grundtvig and the English-Speaking World, Aarhus Univ. Press, 1993; Christian Thodberg and A. Pontoppidan Thyssen (eds): Tradition and Renewal. Grundtvig's Vision of Man and People, Education and the Church, in Relation to World Issues Today, Copenhagen 1983; A. M. Allchin (et. al. eds), Grundtvig in International Perspective. Studies in the Creativity of Interaction, Aarhus, 2000; N. L. Jensen and E. Broadbridge (eds), A Grundtvig Anthology, Cambridge 1984; Johannes Knudsen (ed.), N. F. S. Grundtvig, Selected Writings, Philadelphia, 1976; Vagn Wåhlin, "The 
Growth of Bourgeois and Popular Movements in Denmark ca. 18301870", Scandinavian Journal of History, vol. 5, 1980, 151-183 and the same author in the same journal, vol. 11, 4, "Popular Revivalism in Denmark, Recent Research Trends and Results", 1987, 363-387; William Michelson, "From Religious Movement to Economic Change. The Grundtvigian Case of Denmark", Social History 2, 1968, 283-301; Margaretha Balle-Petersen, "Everyday Rainbows: On social movements and cultural identity", Scandinavian Yearbook of Folklore, vol. 42, 1986, 27 f., Hans Kuhn (1990), Defining a Nation in Song. The standard textbook in English about nearly all aspects of the Danish society up to the end of the modernisation epoch about 1970 in Denmark: An Official Handbook, Copenhagen 1970.

5 The Danish word 'folkelighed' and other compound nouns, using folk/folke as an element, are inventions by Grundtvig and are now generally accepted in Denmark, but are difficult to translate into English; something like 'folkishness' might fit, but here and elsewhere I often prefer 'Danishness'. See also the list of Danish terms at the end of this article.

6 Hanne Sanders and Ole Vind (eds) (2003), Grundtvig - nyckeln till det danska?, Lund.

As in note 4, it is nearly impossible to translate properly the much used Danish word 'åndelig' by one English word - in contrast to material it ranges from 'spiritual' and 'religious' when dealing with the numinous to 'intellectual' and 'cultural' as a psychological and fine arts term.

8 Tidehverv (meaning 1. 'epoch, era, age' 2. 'epoch-making event') is both a theological and later a more popular religious tendency of Dialectical Theology and also the name of a Danish periodical, both expressing the currents from the 1920s directed against the two major Danish Christian movements of the more fundamentalist 'Inner Mission' (Indre Mission, IM, i.e. Home Mission) and the more open 'Grundtvigianism' as well as an opposition to humanistic currents and organisations. Tidehverv is promoting the responsibility of the single individual to God and to his fellow men, yet in a Lutheran sense with no hope of salvation of his own, but only by God's grace. Two influential leaders are the Pastor Søren Krarup, and his cousin, also a pastor, who are MPs for the Danish People's Party, cf. next end note.

9 'The Danish People's Party' (Dansk Folkeparti) is a phenomenon of the 1990s, typical of similar political protest movements throughout the Western world. Many common people feel that they have been betrayed by the leading political parties, which do not listen to them, and they feel threatened by globalisation, migration, multiculturalism, internationalism, economic rationalism and privatisation as demonstrated in June 2005 by the referendums in France and The Netherlands against the European Treaty. Hence parties like the Danish People's Party have arisen in the last 25 years and quickly gained a following. However, the Danish People's Party takes a low profile, unlike that of the more strident, radical and simplistic form taken in similar movements in many other countries. The Danish People's Party was founded in October 1995. In March 1998 the fledgling nartv oained 12 seate in the Danich narliamont 171 nor nont 
of the votes), and in June 1999 it won 22 seats (12 per cent).Thus it has become part of the political landscape in Denmark. The avowed aim of the Danish People's Party is to affirm and protect Denmark's cultural inheritance and national independence. Hence it has pledged to guarantee the freedom of the Danish people in their own country by preserving and promoting representative government and the monarchy, a strong family policy, a stress on law and order, the Danish Evangelical Lutheran Church as the church of the Danish people (while respecting a general freedom of religion), a rejection of migration and of the transformation to a multiethnic society - all as the pillars of the Danish society. This programme indicates how elements of Grundtvigianism mixed with Social-Democracy, petit-bourgeois nationalism and anti-capitalism have seeped deep into the Danish psyche.

10 The concept of private 'free schools' means free from state control; i.e. that a group of parents from the middle of the $1850 \mathrm{~s}$ - and still today organise and finance (nowadays with public support up to 75 per cent of the costs) a private school for their children in opposition to the municipal and, at that time, often rather strictly disciplined school of the General School Law of 1814. Grundtvig inspired the 'free' school system, but the educationist Christen Kold (1816-1870) put it into practice, Birte F. Lund and C. Oxenvad (2003), Freedom of Thought (about Kold). Most folk high schools are constituted on a similar basis as private educational institutions for the youth and adults, not rejecting knowledge but emphasising personal development and engagement in society as proper citizens. Also now after 2000 the existing 80 folk high schools are heavily subsidised by public funding.

11 The Inner Mission, Indre Mission (IM), was and is a revivalist religious faction of lay people within the State Church of Denmark, founded in 1854. In 1861 the IM was restructured as Kirkelig Forening for den Indre Mission under the strong dominance of the clergy and, until 1901, the strict leadership of Pastor Vilhelm Beck, who also edited the still surviving and influential weekly, Indre Missions Tidende. The IM here in the $21^{\text {st }}$ century has a following of some 50,000 with a variety of subinstitutions and a growing influence on the youth, often inspired by North American revivalist Lutheran movements.

12 From the 1880s the Danish dairies adopted a collective and more industrial handling of the farmers' milk for the production of butter and cheese and at the same time the whole dairy industry underwent an expansion of distribution and export abroad. Moreover, the Danish model was adopted in several modern agrarian societies, such as Canada, New England and the Middle West of the USA, Australia and New Zealand. The special, innovative Danish way in the dairy industry was the form of collectively owned and run co-operative dairies, which after 1890 became dominant in Denmark and elsewhere. The co-operative pattern suited the prevailing middle-size family farms of the country so well that it soon spread to many other fields of economic activity, first in the agricultural sector and later, from 1900, in the towns, where great interest was shown by the labour movement, and about 1950 the Danish cooperative movement was at its peak. as described in English by Ravnholt 
(1950), The Danish Co-Operative Movement. Dr John Stanley Martin (note 2) has kindly informed this author, that immigrant Danes followed the same pattern in Victoria and New South Wales in Australia, between 1890 and 1914, where they set up butter factories on a co-operative basis, see Martin, John Stanley (1988), 'Danes and the Australian Dairying Industry' in Danish Emigration to Australia, ed. Kristian Hvidt and Helle Otte, 108-116.

13 The Danish Athletic Association (Dansk Idrcets Forbund), The Danish Gymnastic and Sports Associations (Danske Gymnastik- og Idratsforeninger) and The Danish Company Athletic Union (Dansk Firmaidratsforbund) organise together a third of the population, young and old, in participation in sport under the active leadership of 200,000 trainers in 9,100 football fields, club houses, gymnasiums and similar institutions on a voluntary basis. They are subsidised by state and municipal funding, receiving in the 1990s more than one per cent of the total national budget. The active membership of these organisations is about ten times higher than that of the organised political parties together, cf. a summary in the paper Jyllands-Posten, $9^{\text {th }}$ September, 2003, 14. The individual organisations are described in articles in Den Store Danske Encyklopadi, vol. 4, 1996, 'Danmark', 'Idræt og Sport', 492.

Cf. an article in Jyllands-Posten, $31^{\text {st }}$ May 2005, 5, in the section 'Indland'. Immigrant organisations are nevertheless short lived, often less than a year, compared to the more stable Danish voluntary organisations, which are often more than 100 years old. Thus immigrant organisations do not have the same influence as the more established Danish organisations, partly due to a lack of skilled leadership and partly due to a lack of loyalty to the cause from the members, who are more guided by loyalty to the faithful, to the clan, to the extended family and to those of the same language when conflict arises.

15 The first folk high school in the Danish realm was established in 1842 by the Germanophile upper classes in Rendsborg on the Slesvig border to Holsten to educate the peasant-farmers of the Assembly of the Estates in Slesvig. In 1844 it was followed by a national Danish folk high school in Rødding near the boarder between Slesvig and Denmark, established by intellectuals from Copenhagen, Slesvig and Kiel and a few Slesvigian farmers with a programme based on Grundtvig's educational philosophy and similar to that of the Rendsborg folk high school. Because of the great success of the folk high school among the peasant-farmer class from the 1860 s, a national myth developed that the folk high schools were a pure Danish invention. Neglect of the Rendsborg forerunner was continued by Borish et al., cf. the survey by Hans Henningsen, "Højskole i 150 år-bøger omkring et jubilæum”, Grundtvig-Studier 1995, 193-204; about the Rendsborg farmers' school, V. Wåhlin (1994b), "Grundtvig i politik op til 1830", and Wåhlin (1994a) with Grundtvig's text.

The co-operatives and the Danish dairy industry, cf. note 12.

17 Even before the new Constitution of 1849 , the peasant-farmers were organised along class lines under the leadership of some of their own members and a few left-wing Liberals. Divided into several factions, the neasant-farmers nnited in 1870 as a more colid narliamontare narter in the 
Lower House (Folketinget) against the co-ordinated forces of the old National-Liberals, the great landowners and the city capitalists, who dominated the Upper House (Landstinget) from 1866 to 1901 and constituted the basis of the Conservative governments up to 1901. Having dominated the Folketinget for many years, the Leftist Venstre parti transferred the political power to Folketinget, where they have played a central political role in the changing alliances to this day, 2005; H. Lund (1970), Venstre i 100 år.

18 The youth of the Grundtvigian movement and the Inner Mission had been organised locally in rather loose networks before 1900. After that time the Inner Mission learned from the Anglo-Saxon countries the efficiency of stricter and often uniform and centralised youth organisations, such as The Young Men's Christian Associations (YMCA) and The Young Women's Christian Associations (YWCA), in Danish as Kristelig Forening for Unge Moend (KFUM) and Kristelig Forening for Unge Kvinder (KFUK), both locally in the countryside and in the rising cities, where so many young people had migrated. Such Christian institutions often became the social framework for a meaningful life and a shield against loneliness and the temptations of urban life. The Scout movement and many sport and athletic clubs functioned in the same direction, and just because they 'kept the youth off the streets', they soon won broad public support. The different Christian Scout organisations for the children and young people (both boys and girls) under 20 years of age became very popular after 1910. In January 2004 they still numbered 82,400 , while the only non-religious parallel movement of significance, the Social-Democratic DUI-Leg-og-Virke, numbered 1,892 compared to a world figure of some $28,000,000$ scouts. The scouts are to some extent subsidised by the Danish state according to the number of members and the statistics are published every year, cf. an article in Jyllands-Posten, Indblik, $10^{\text {th }}$ July 2005, 6-7.

19 Concerning the Period of Absolutism; cf. comments to Map 1.

20 The above quotation and the original Danish versions from V. Wåhlin (1986a), "Opposition og statsmagt" in Flemming Mikkelsen (ed.), Protest og oprør (Protest and Insurrection), Aarhus, 1986.

21 Konventikelplakaten, decrees from the government in the name of the king were made public as placards glued on the walls or read by the pastors at the Sunday services.

22 Inside the general Lutheran world several currents occurred, including Pietism, which concentrated on the inward strength of faith and spiritual piety. It had a certain influence in Denmark between 1700 and 1850 .

23 The Royal Danish Agricultural Society (Det Kongelige Danske Landhusholdningsselskab from 1769) was perhaps the most influential of the Royal Societies (parallel of the English and French Royal Societies), which published thousands of educational booklets on the improvement of daily farming etc. In these societies the élite was allowed an open and free debate on most social matters.

24 After the Great Fire in Copenhagen of 1728, the slow rebuilding of the city led the government to introduce a Fire Insurance Society, with compulsory membership, but a rather free annual general meeting and an 
The system of Estates was prevalent over most of Europe from the Middle Ages to modern times, as the legal form of representative bodies for the four major social groups in society: (in Denmark) the nobility, the clergy, the burghers and the free farmers with the task of assisting the royal power in the issuing of laws, the levelling of taxes etc. In Sweden each of the four estates had its own House of Representatives until the 1860s; in England the nobility and the higher clergy formed the House of Lords, while the gentry, the city burghers and some upper yeomen formed the House of Commons; in France the untaxed aristocracy and the Church each formed a house, while the 'Third Estate' consisted of city burghers and some well-off farmers who paid most of the taxes and a meeting of all the estates was named the 'Estates General'; in Germany each principality had its own specific representation of the estates, which met as Landtag and for the whole Empire as the Reichstag. One of the actual goals of Danish Absolutism was to minimise or totally abolish the influence or existence of the estates and similar representative bodies. The Danish constitutional Royal Law of 1665 gave no room for representative estates, neither in legal form nor in practice, and in reality it was the expression of the most concentrated system of state power in contemporary Europe. The mere name of the Assemblies of the Estates (stcenderforsamlinger) in the Danish version from 1834 gave a historical value to the four advisory and not decision-making assemblies of the lands of Holsten, Slesvig, Jutland and Zealand/Copenhagen, in each of which the landed aristocracy, the clergy, the more affluent burghers and the middle farmers elected their representatives from among their own ranks. In practice, the government took the advice of the Estates seriously, and the elections to and debates in the assemblies contributed much as a preparation for the introduction of parliamentary democracy in Denmark in 1849.

Quotations in Danish from the Police Archives are printed in Wåhlin (1986a), 121-23.

Steen Steensen Blicher (1782-1848), Danish pastor, poet and writer, introduced Jutland and the writings in dialect into Danish literature. Blicher was a national-patriot and royalist, but not a democrat. Inspired by the pan-German Wartburg populist meetings between 1839 and 1844, he organised festivals at the spectacular Himmelbjerget with some success with up to 4,000 participants.

Skamlingsbanke is a steep hill near the Danish-Slesvig border, later a Danish national symbol.

32 The original in Danish is from Grundtvig's still popular hymn 'Vidunderligst af Alt paa Jord', 1829/1837, stanza 3, "Dets Gaade er et Guddoms-Ord / Som skaber, hvad det nævner"; in N. F. S. Grundtvig, Sang-Verk til den Danske Kirke, 1837, nr. 1 has as stanza 10, "Min 
Gaade er (...)", cited here from the reprint of 1982, I,1,34; the editions in the Danish Hymn-book and the Folkehøjskole Sangbogen (the Folk High School Songbook) are shortened and corrected.

33 Henning Tjørnehøj, the Social-Democratic politician and former Labour folk high school educator, is just one of many, who in the last 25 years in speeches and writings have attacked Grundtvig and his form of nationalism as being outdated and in reality as being anti-social and against the common man's fundamental interests in a modern welfare state. Even the titles and quotations from three articles will suffice to indicate their point of view: 'Den ufolkelige Grundtvig' (The un-'folksy' Grundtvig, Berlingske Tidende, 13.02.2004, 2); 'En folkeligheds som Grundtvigs, der ikke omfatter hele folket, har ikke meget med folkelighed at gøre' (a 'folkishness' like Grundtvig's, which does not include all of the people has little to do with 'folkishness', Kristeligt Dagblad, 05.12.2004, 9). Tjørnehøj generalises that Grundtvig, like most of the leading people of the Farmers' Party in the late $19^{\text {th }}$ century, regarded poverty as a God-given condition, Kristeligt Dagblad 06.03.2005.

The nationalistic poet, Valdemar Rørdam, influenced by the loss of Slesvig in 1864 and by the First World War, has expressed in several songs printed in the Folkehøjskolens Sangbog that a people, which by fear or inner strife is not willing to fight to the uttermost for its existence will, in the end, lose just that very existence, or in Danish ' $\mathrm{Vi}$ ved, at Fjæld kan sprænges, og tvinges kan en Elv, men aldrig kan et Folk forgå, som ikke vil det selv', from 'For Danmarks frie Flag', stanza 7 (Den gamle Kaptajn,1907), quotation from H. Stangerup, Danmarks store Digtere, II, 1944, 260-261.

35 A check on the internet of the attitudes of politicians from the Danish extreme left in Folketinget (the Danish Parliament), called Enhedslisten the Unity List - (Pernille Rosenkrantz-Theil) and the strictly nationalist Danish People's Party in the European Parliament (Mogens Camre) towards such key-words as 'globalisation' and 'verdensborger' (citizen of the world) demonstrates through a few links, that these two parties are the most convinced and concerned about the fact that it is the ordinary Danish wage-earner, who is going to pay the price for globalisation and the sinking influence of the national state.

Vilhelm Beck (1829-1901), pastor, religious leader and writer, was especially influential as chairman of the religious Inner Mission (Home Mission) and editor of the weekly Indre Missions Tidende 1861-1901. Beck's national sentiment is presented in K. Larsen (2001), Vilhelm Beck, 241-244. Cf. note 11.

37 The landlords controlled 2,000 estates and cultivated 10 per cent of the land, the 100,000 peasant farmers controlled 75 per cent of the land, while about 200,000 cottagers and smallholders in 1900 occupied just 12 per cent of the cultivated land. Not until around 1900 did the smallholders and agrarian proletariat start organising in defence of their interests. Folkehøjskolens Sangbog, 1972, no 449-50 and no 451 by Anders Dolleris, 1919, "Nu rinder Sol i sin Vælde" especially stanza 2 and 3.

38 Oscar Hansen. "Danmark for Folket", text in Folkehøjskolens Sangbog, 1972, no. 456. 
Kanslergade, the name of the street where the Social Democratic prime minister, Th. Stauning, lived at that time, cf. note 40.

All Danish textbooks from the period and even from today agree on the importance of the Compromise of 1933. Opinions may differ on the details; Kaarsted and Samuelsen (1967), Kanslergadeforliget. Schultz Hansen (1998).

42 There are no standard books in English about the Danish temperance and women's movements. The best overview in Danish is still Gundelach (1988) and in other Scandinavian languages for comparisons within Scandinavian conditions A. Gustavsson (1993), Kulturforskning kring alkohol $i$ Norden, Uppsala.

43 A few years ago this author, together with the Professor Drude Dahlerup, now at the University of Stockholm, lectured in a joint course on social and popular movements. As co-founder and spokeswoman of the very lively Aarhus'Red-stockings', she realised that their time as a movement was up in 1995 and called for the holding of a wake, a grand closing party attended by more than thousand former Red-stockings. They had to rent the largest hall in town for the party, but also agreed with Drude, that it was the time to close the movement. None of the many young female students attending the lectures took any topic from the former or later women's movement for their theses later in the course - and none have done so for the chapter-topics in the Centre for Grundtvig Studies' forthcoming book on popular movements.

44 Danskeren $20^{\text {th }}$ August 1848 , stanza 14 (everything is real Danish since) "Ei paa Val og ei paa Thinge / Agtes Børn og Kvinder ringe; / Hvad der end gaaer op og ned, / Dansk er immer Kiærlighed." The text in Folkehøjskolens sangbog (1972) is shortened and modernised in the spelling.

45 The Danish word ting refers to the ancient local moot in medieval times as well as a parliament or a law court in modern times

Peter Gundelach (1988) in his introduction (cf. note 50) and Professor Drude Dahlerup in her opening lectures (cf. note 43) both referred to these, mostly American, broader concepts of 'social movements'; the author's understanding of 'popular movements' lies within the description as 'social' but not all social movements have the morally uplifting idea of a 'folkelig' (popular) movement.

The text of Grundtvig from 'Mands Minde' 1838/39 about the industrial proletariat is reprinted and commented on in Wåhlin (1986b).

The first economic organisations were insurance companies and agricultural educational associations and they were formed by the peasant-farmers themselves in the 1840 s, while their few forerunners often were initiated by well-meaning landlords and pastors etc. A number of M.A. history students from the University of Aarhus under the supervision of the author have mapped these local institutions - they can be read (unfortunately only in Danish) at the departmental library. In a forthcoming book on 'Folkelige bevcegelser' (Popular Movements, the end of 2006). Some 15 of these studies will be edited.

The Farmers' Party was Liberal but called 'Leftist' (Venstre), its position being seen as a narallel to that of the third ectate in the Franch 
Revolutionary Parliament. The outermost Liberal wing of Venstre, then being a new party from 1905, was called the 'Radical Left' because of its smallholder outlook; today it is known as 'Det radikale Venstre', which in the current international spectrum is something like 'Liberal'. There is no recent English study on the history and influence of Venstre; the best study in Danish is H. Lund, A. F. Pedersen, J. H. Monrad and C. P. Fogtmann, Venstre i 100 år, I-III (1970).

50 Gundelach, in his introductory chapter (1988), writes about theory at the threshold of the opening up to the 'softer' intellectual and ideological dimensions of the social movements, but hesitates with a remark that V. Wåhlin is doing so on his way in the opening up of perhaps promising and broader research horizons - unfortunately Gundelach says so without specifying these horizons.

51 The real break-through of the folk high schools came after the Danish defeat by Prussia in 1864 and the subsequent loss of Slesvig, strengthening sentiments of both patriotism and of peace. The older military training practices were replaced by new systems of bodybuilding and a strengthening of 'a sound mind in a healthy body'. The new and more elegant form of gymnastics came from Sweden, inspired by the educator, Pehr H. Ling (1776-1839), and his followers at the State Institute in Stockholm.

52 The system of co-operative stores for good and cheap commodities for the members of the local co-op store spread in the last decenniums of the $19^{\text {th }}$ century all over the countryside and after 1900 in Copenhagen and the towns as well. Soon the co-operatives had built factories and organised mass imports covering the total range of daily commodities needed by their membership, cf. Ravnholt (1950), The Danish CoOperative Movement. Even after the year 2000 the co-operative stores in Danish called 'Brugsen' or 'Kvickly' - are one of the largest chain of wholesale and retail stores in Denmark with a branch in nearly every village and in all the towns throughout the country; 'Brugsen' is dealt with in the forthcoming Folkelige bevagelser, cf. note 48.

53 In Peter Gundelach: Sociale bevcegelser og samfundsforandringer, Århus, 1988 , and other studies on social research we find a tendency to prefer simplistic explanations and a belief in that all of Denmark followed the same general pattern of modernisation, thus ignoring the fact of the two different lines of approach in the agricultural and the urban sectors and of the time gap between their responses to national and especially international tendencies of modernisation

54 The Kerteminde Revival on the island of Fyen in 1820 and the 'Strong Jutlanders' in Mid-East Jutland of the same period are the two wellknown cases of clashes between local religious revivalism and parsons with no understanding of the emotions of their parishioners. When the cases could not be handled and solved on the spot, they became a police matter and were brought before the court, since both the Church and the breaking of its regulations were a matter concerning the state; punishments were severe, but in a way confirmed the believers in the revival that through persecution they were the true disciples of Christ. After 1840. the authorities secretlv gave in and the court cases stopped. 
This subject is presented in an article in the forthcoming book Popular Movements, cf. note 48.

55 By royal decree the German Pietistic movement from Herrnhut in 1773 was allowed to build Christiansfeld in North-East Slesvig as their centre in Denmark-Norway. Many supporters of the popular religious movements were pupils at the boarding school there or had life-long contacts with their lay delegates, acting as travelling emissaries, (from the Latin e-misso 'I send out').

56 The Inner Mission colporteurs had a similar role as the Christianfeld emissaries, being lay people acting as travelling religious agents, who carried around (or 'col-ported') and sold religious literature for the benefit of the Inner Mission.

57 Most parishes and often single villages of Denmark up to the 1970/80s had their own co-operative store, often in fierce competition with a village grocer (en fri købmand) independent of the big chain stores, a local co-operative savings bank or a co-o;erative bank branch, a community or meeting house, a co-operative dairy, a municipal or a 'free' school, a private blacksmith and some other craftsmen and one or two sport clubs with names like 'Forward', 'Unity' or the name of the village and, last but not least, the parish church some 800 years old. Now, after the year 2000 , most often only the church and one or two other institutions are left.

During 1991-2003 the author lived in Gjellerup Parken, Aarhus West, with a high immigrant element amongst its 10,000 residents, and for 11 years was vice-chairperson of the board of 'Block 6'. He knows that life is easier out there for a well functioning academic - even with less money - than for the immigrants.

59 In the Anglican Church in several countries 'The Church Army' has a similar function to that of Kirkens Korshor in Denmark, exercising broad, practical welfare.

60 The words from the last congress speech of former union chairperson, Thomas Nielsen, in 1982: 'Ja, vi har sejret - (hele vejen) ad helvede til godt!' (Yes, we have been victorious - all the way to hell - good) have become nearly a proverb; http://www.pladstilosalle.dk/baggrund/ persongalleri/29.html - Thomas Nielsen, 'Criticism of fossilisation of the Danish Trade Unions (LO)' in Schmidt and Wechselmann (1970), Den danske fagforstening.

61 '(...) lad falde, hvad ikke kan staa', second line in last stanza of U. T. Overbye's 'Socialisternes March - Snart dages det Brødre', from 1872, in Folkehøjskolens sangbog (1972), no. 455 - shortened here as in Miniavisens lille blodrøde sangbog (1972) 13-14; Grundtvig's words, 'kun Livet sig rører i Strid, (...) mit Liv er i Kamp' from 'Rimbrev til nordiske Paarørende' (postscript to) Nordens Mythologi, 1832 - here from V. Wåhlin's edition as postscript to Wåhlin (1986b) 53. 